\title{
Hydrochemical Characteristics of Groundwater - Assessment of Saltwater Intrusion Along Krishna Godavari Delta Region, Andhra Pradesh, India
}

Kannan Rajaiah ( $\square$ maadhukanna@gmail.com )

Andhra Pradesh State Remote Sensing Applications Centre https://orcid.org/0000-0001-6189-2194

K.Appala naidu

Andhra Pradesh State Remote Sensing Applications Centre

Abhrankash Kanungo

Andhra Pradesh State Remote Sensing Applications Centre

M.V.Ramana Murty

Andhra Pradesh State Remote Sensing Applications Centre

K.V. Ramana

Andhra Pradesh State Remote Sensing Applications Centre

\section{Research}

Keywords: Groundwater, Hydro-chemical Characteristics, Saltwater Intrusion, Krishna Godavari Delta, Piper diagram, Seawater Mixing Index

Posted Date: January 19th, 2021

DOI: https://doi.org/10.21203/rs.3.rs-148451/v1

License: (c) (i) This work is licensed under a Creative Commons Attribution 4.0 International License. Read Full License 


\section{Abstract}

The Intrusion of saltwater into a freshwater aquifer is of particular concern to the coastal community. Removal of excess groundwater from the shallow aquifers is known to be the primary cause of contamination by saltwater. In this study, groundwater samples were obtained in the 2016 and 2017 premonsoon and post-monsoon seasons at 105 locations from dug wells and bore wells along the coast of Andhra Pradesh in the Krishna and Godavari deltas. Groundwater samples are tested for large ions to determine the infiltration of salt water and to classify the salinity sources in the delta zone. The Various hydro-geochemical parameters such as pH, Electrical Conductivity (EC), Total Dissolved Solids (TDS), $\mathrm{Ca}^{2+}, \mathrm{Mg}^{2+}, \mathrm{K}^{+}, \mathrm{Na}^{+}, \mathrm{CO}_{3}, \mathrm{HCO}_{3}{ }^{-}, \mathrm{Cl}^{-}$, and $\mathrm{SO}_{4}{ }^{2-}$ are evaluated for the delineation of the intrusion of saltwater in terms of $\mathrm{Ca}^{2+} / \mathrm{Mg}^{2+}, \mathrm{Cl}^{-} /\left(\mathrm{CO}_{3}+\mathrm{HCO}_{3}{ }^{-}\right), \mathrm{Na}^{+} / \mathrm{Cl}^{-}$ratios. It is reported that the availability of fresh groundwater is $14 \%$ and $62 \%$ respectively during the pre-monsoon and post-monsoon seasons. The percentage levels of contamination in groundwater for slight, moderate, injuriously, highly, and severely categories are $43 \%, 22 \%, 12 \%, 8 \%$, and $1 \%$ respectively for pre-monsoon season. However, during the postmonsoon season, the levels of contaminations in the above- mentioned categories are $22 \%, 9 \%, 4 \%, 1 \%$, and $3 \%$. The extent of contamination during the post-monsoon season is observed to be lower than during the pre-monsoon. The groundwater ratio of $\mathrm{Na}^{+}-\mathrm{Cl}^{-}$during pre-monsoon and post-monsoon seasons is $71 \%$ and $60 \%$ respectively. The Saltwater Mixing Index (SMI) is also measured, and extremely high is found.

\section{Introduction}

Freshwater is life's main tool. The growth of the population in water-scarce regions would only increase the demand for available resources. While water is the most commonly used material available in the natural world, it is not spread evenly across the globe (Tulipano et al. 2008, Sudhakar et al. 2013). Just $0.69 \%$ of aggregate water can specifically fulfill human needs (Vasanthavigar et al. 2010, Anil Kumar et al 2015). Coastal regions are generally vulnerable to infiltration by seawater, particularly in areas where over-pumped groundwater. Owing to the over-extraction of groundwater, saltwater intrusion is the major concern in coastal areas and it leads to the destruction of freshwater aquifers' excellence (Annapoorani et al.2014, Chen K.P.et al 2007). The Ghyben-Herzberg ratio states that, for every meter of fresh water in an unconfined aquifer above sea level, there will be forty meters of fresh water in the aquifer below sea level. Recognizing the extent of the intrusion of seawater is necessary to prevent the depletion of groundwater quality. The main causes of the decline in groundwater levels in the coastal aquifer are high water demand for various domestic, agricultural, industrial purposes, and rainfall recharge lower than groundwater depletion (Nair et al. 2013). Groundwater is the water found under saturated conditions at the interstices of rock formations, and it is one of the earth's most significant natural resources. This is necessary for the earth's sustenance and growth and it forms an integral part of the natural environment. The consistency of groundwater is dependent on physical properties such as color, odor, turbidity, and chemical elements such as large cations and anions. Water's physical and chemical characteristics alter spatially and momentarily and are caused by natural causes, human action, and infiltration of seawater 
in coastal areas. (Narayan et al.1993). The flow of seawater into freshwater raises the recorded concentrations of electrical conductivity, sodium and chloride, and groundwater ratio $\mathrm{Cl} / \mathrm{HCO}_{3}$ (Venkateswaran, 2001, Sreedevi,2004).

The intrusion of seawater is a significant source of increased salinity, and groundwater typically demonstrates high concentrations not only of total dissolved solids (TDS) but also in cations and anions (Richter and Krietler, 1993), as well as selective trace element rises (Saxena et al.2004; Mondal et al.2010b). The intrusion of seawater is characterized as the movement of saline water from the sea into a freshwater aquifer which is hydraulically attached to the shore. In densely populated coastal areas with greater groundwater dependency, the depletion typically exceeds the rate of regeneration resulting in intrusion by seawater. Seawater densities are slightly greater than freshwater concentrations (Magesh.N.S et al.2016). When intrusion of seawater is a significant cause of high salinity, groundwater typically exhibits high concentrations not only of total dissolved solids (TDS) but also of other different chemical constituents, such as $\mathrm{Cl}-, \mathrm{Na}^{+}, \mathrm{Mg}^{2+}$, and $\mathrm{SO}_{4}{ }^{2-}$ (Richter and Kreitler,1993) as well as aggregation of identified trace elements (Saxena et al.2004; Mondal et al.2010b).

The normal balance between freshwater and saltwater in waterfront aquifers is aggravated by groundwater withdrawals and other human exercises. Henceforth individuals living in the lake zone are getting drinking water from far spots, which demonstrates the accessible groundwater in the lake region isn't consumable (Pujari et al.2009, Subba Rao et al.2005). Comprehension of saline interruption into the beachfront aquifers is fundamental for productive arranging and the executives of seaside aquifers (Saha et al.2005). It is likewise fundamental to portray and foresee the degree of saline water interruption into the aquifers in light of varieties in the segments of the freshwater mass-balance (Rajib Paul et al 2019). Over-exploitation of groundwater results in the decline of water levels, leading to the intrusion of saltwater along the coastal region, which is a natural phenomenon (Brindha et al.2016). Saltwater intrusion can pose serious problems to freshwater aquifers along the coastal areas having marine aquifer hydraulic interaction (Giuseppe Sappa et al.2012,). Coastal aquifers are contaminated with saltwater intrusion particularly in and around the region, mainly because of the growing demand for seafood, has led many farmers to take up aquaculture as a more profitable source of income, where saltwater is used from the nearby creaks (Bear 1999, Ashraf Ali at al.2019). The water quality in these aquaculture tanks is usually saline, which slowly infiltrates and reaches the water table. The aquifers in this region were contaminated with saltwater. Hence, the objective of this study is to identify the extent of seawater intrusion area in the Krishna Godavari delta regions based on the groundwater sample collection for wells and dug wells.

\section{Study Area}

The Krishna - Godavari delta region is covered in four districts i.e., Guntur, Krishna, West Godavari, and East Godavari district, Andhra Pradesh, India. The study area lies between $80^{\circ} 27^{\prime} 58.44^{\prime \prime} \mathrm{E}, 15^{\circ} 54^{\prime} 37.88^{\prime \prime} \mathrm{N}$ to $82^{\circ} 32^{\prime} 8.06^{\prime \prime} \mathrm{E}, 17^{\circ} 15^{\prime} 16.85^{\prime \prime} \mathrm{N}$ (fig:1). The total area of study stretches about $360 \mathrm{~km}$ long with a width of $12 \mathrm{~km}$. The area is bounded by the Bay of Bengal in the east, the Guntur in the south, and the East 
Godavari on the north. The temperature ranges from 20 to $37^{\circ} \mathrm{C}$ (winter seasons) and from 35 to $42{ }^{\circ} \mathrm{C}$ (summer seasons). The highest temperature occurs from May to June (Central Groundwater Commission, 2015). The average monthly humidity in June was $65 \%$, and the average monthly humidity in November was $91 \%$. The monthly evapotranspiration ranges from $4.2 \mathrm{~mm} /$ day to $8.2 \mathrm{~mm} /$ day. Geologically, the area consists of alluvial layers. Alluvial sediments are the youngest strata composed of sand and clay, deposited by river areas. Groundwater exists in unrestricted and confined aquifers in alluvial and weathered crystalline square-pore Rock layers.

\section{Sampling And Analytical Procedure}

Groundwater samples representing the pre-monsoon and post-monsoon seasons were collected from 105 locations in June 2016 and January 2017 (Fig. 1). The collected samples were analyzed in the laboratory using the standard method of the American Public Health Association (APHA, 1995) to measure the concentration of quality parameters. The samples were collected in a one-litter capacity high-density polyethylene (HDPE) bottle, and the $\mathrm{pH}$, conductivity (EC), major cations, and anions of each groundwater sample were analyzed. The $\mathrm{Ca}^{2+}, \mathrm{Mg}^{2+}, \mathrm{Na}^{+}, \mathrm{K}^{+}, \mathrm{HCO}_{3}{ }^{-}, \mathrm{CO}_{3}, \mathrm{SO}_{4}{ }^{2-}$, and $\mathrm{Cl}^{-}$are the main ions in groundwater in the study area. The $\mathrm{pH}$ and $\mathrm{EC}$ were measured by using a Systronics micro $\mathrm{pH}$ meter. The concentrations of calcium and magnesium are determined by EDTA titration, using a chrome black T indicator. Determine the sodium and potassium concentrations by using a flame photometer. The chloride concentration was determined by silver nitrate titration. The carbonate and bicarbonate concentrations are measured by acid-base titration. The measuring concentration of Sulphate and nitrate with a colorimetric spectrophotometer. The main water chemical phase was determined by Piper Trilinear diagram (Piper 1944) using Aquachem Scientific v4.0 software. The analysis accuracy of the main ions was cross-analyzed from the ion balance of all samples within $\pm 7 \%$. The formulas proposed by Lloyd and Heathcote (1985) and Sawyer and McCarty (1978) were used to calculate the total dissolved solids (TDS) and total hardness (TH) of water, respectively.

$\operatorname{TDS}(\mathrm{mg} / \mathrm{l})=\mathrm{EC}(\mu \mathrm{S} / \mathrm{cm}) \times 0.64$

$\mathrm{TH}(\mathrm{mg} / \mathrm{l})=2.497 \mathrm{Ca}^{2+}(\mathrm{mg} / \mathrm{l})+4.115 \mathrm{Mg}^{2+}(\mathrm{mg} / \mathrm{l})$

\section{Spatial Interpolation Methods}

Spatial interpolation is the process of using points with known values to estimate values at other points. In GIS applications, spatial interpolation is typically applied to a raster with estimates made for all cells. Spatial interpolation is therefore a means of creating data from sample points. The Arc Map version 10.3 was utilized to foresee values in un-examined areas. Estimated values encompassing an unmeasured area are utilized for expectation. The Inverse Distance Weighted (IDW) strategy was utilized for this investigation. After linking the spatial and non-spatial data together, the groundwater auxiliary data and spatial data (coordinates) collected by GPS are combined in GPS 10.3 software, and the groundwater quality point layer is generated for further analysis. IDW is a local deterministic spatial interpolation 
method, which estimates continuous values by weighted averaging the values related to the values of known positions. In this technique, the weight of sampling points located within the average distance is higher than the weight of points farther from the average distance. The advantage of IDW is its instinct mastery, which works best when distracting the focus, and is extremely sensitive. IDW has two assumptions. When choosing this technique, one assumption must be kept in mind. It is assumed that the data sets are automatically linked not clustered. These studies will use IDW interpolation methods and IDW and barrier interpolation methods.

\section{Results And Discussion}

The analysis results are listed in Table: 1 is the study area before and after the 2016 and 2017 monsoons. Table 1 summarizes the chemical analysis of groundwater and the percentage of Indian standards. The table lists the water quality parameters of 105 groundwater samples (BIS, 2005 and WHO, 2011).

Table: 1. Water quality variables represented by BIS (2005) and WHO (2011) for drinking uses and the number of samples from the Krishna Delta Godavari delta surpassing the maximum permissible values 


\begin{tabular}{|c|c|c|c|c|c|c|}
\hline $\begin{array}{l}\text { Chemical } \\
\text { Parameters }\end{array}$ & $\begin{array}{l}\text { WHO } \\
\text { Standard }\end{array}$ & $\begin{array}{l}\text { BIS } \\
\text { Standard }\end{array}$ & $\begin{array}{l}\text { No. of } \\
\text { sample } \\
\text { Exceed } \\
\text { Permissible } \\
\text { limit }\end{array}$ & $\begin{array}{l}\text { Percentage of } \\
\text { sample } \\
\text { Exceeding } \\
\text { Permissible } \\
\text { limit }\end{array}$ & $\begin{array}{l}\text { No. of } \\
\text { sample } \\
\text { Exceed } \\
\text { Permissible } \\
\text { limit }\end{array}$ & $\begin{array}{l}\text { Percentage } \\
\text { of sample } \\
\text { Exceeding } \\
\text { Permissible } \\
\text { limit }\end{array}$ \\
\hline & \multicolumn{4}{|c|}{ Pre-Monsoon (2016) } & \multicolumn{2}{|c|}{ Post-Monsoon (2017) } \\
\hline $\mathrm{pH}$ & $6.5-8.5$ & $6.5-8.5$ & 2 & 1.9 & 0 & 0.0 \\
\hline $\begin{array}{l}\mathrm{EC} \\
(\mu \mathrm{S} / \mathrm{cm})\end{array}$ & 1500 & 1500 & 73 & 70.2 & 70 & 67.3 \\
\hline $\begin{array}{l}\mathrm{HCO}_{3}^{-} \\
(\mathrm{mg} / \mathrm{l})\end{array}$ & 600 & 600 & 25 & 24.0 & 76 & 73.1 \\
\hline $\mathrm{Cl}^{-}(\mathrm{mg} / \mathrm{l})$ & 600 & 1000 & 32 & 30.8 & 27 & 26.0 \\
\hline $\begin{array}{l}\mathrm{SO}_{4}^{2-} \\
(\mathrm{mg} / \mathrm{l})\end{array}$ & 400 & 400 & 0 & 0.0 & 0 & 0.0 \\
\hline $\mathrm{Ca}^{2+}(\mathrm{mg} / \mathrm{l})$ & 200 & 200 & 8 & 7.7 & 9 & 8.7 \\
\hline $\begin{array}{l}\mathrm{Mg}^{2+} \\
(\mathrm{mg} / \mathrm{l})\end{array}$ & 150 & 100 & 26 & 25.0 & 24 & 23.1 \\
\hline $\mathrm{Na}^{+}(\mathrm{mg} / \mathrm{l})$ & 200 & 200 & 73 & 70.2 & 69 & 66.3 \\
\hline $\mathrm{K}^{+}(\mathrm{mg} / \mathrm{l})$ & 30 & 12 & 79 & 76.0 & 78 & 75.0 \\
\hline TDS (mg/l) & 1500 & 2000 & 40 & 38.5 & 45 & 43.3 \\
\hline
\end{tabular}

$\mathrm{pH}$ is a measure of the balance between the concentration of hydrogen ions and hydroxide ions in water. Before the monsoon season, the pH varied between 6.9 and 8.8 (average 8.0) (Fig. 2). Most samples are alkaline. After the monsoon, the pH (Fig. 3) varied between 6.8 and 8.0, with an average value of 7.3. It was observed that all samples were within the allowable range. When Inverse Distance Weighting (IDW) interpolation technology was used to generate a pH map, it was found that the village of

Pandurangapuram in Bapatla Mandal had the highest $\mathrm{pH}$ of 8.8. According to the BIS standard, the water exceeded the allowable limit. Total Dissolved Solids (TDS) is an important parameter in drinking water and other water quality standards. TDS stands for various minerals in dissolved form in water. In natural water, the dissolved solids are mainly composed of carbonate, bicarbonate, chloride, sulfate, phosphate, silica, calcium, magnesium, sodium, and potassium. The TDS is calculated by Eq. (1).

According to WHO (1993) specifications, the maximum allowable maximum TDS is $500 \mathrm{mg} / \mathrm{l}$ and the maximum allowable is $2000 \mathrm{mg} / \mathrm{l}$. In the study area, the pre-monsoon TDS value varied between a minimum of $256 \mathrm{mg} / \mathrm{l}$ and a maximum of $18560 \mathrm{mg} / \mathrm{l}$, which indicated that most groundwater samples exceeded the maximum allowable limit. According to Davis and De Wiest (1966), TDS-based groundwater classification (Table. 2) was $29 \%$ before the monsoon and $24 \%$ was allowed to drink after the monsoon. 
In the post-monsoon season, $36 \%$ is suitable for irrigation before the monsoon, and $39 \%$ is suitable for irrigation after the monsoon. As shown in Fig. 4 and Fig. 5 , in both seasons, about $30 \%$ and $28 \%$ of the samples are not suitable for drinking and irrigation, before the monsoon, $5 \%$ of the samples are suitable for drinking, and not $9 \%$ after the monsoon

Table 2

David and Dewiest classification of groundwater based on TDS (mg/l).

\begin{tabular}{|llllll|}
\hline $\begin{array}{l}\text { TDS } \\
\text { (mg/l) }\end{array}$ & Classification & \multicolumn{2}{l|}{ Pre-monsoon (2016) } & \multicolumn{2}{l|}{ Post-monsoon (2017) } \\
\cline { 3 - 6 } & & $\begin{array}{l}\text { Number of } \\
\text { samples }\end{array}$ & $\begin{array}{l}\text { Percentage } \\
(\%)\end{array}$ & $\begin{array}{l}\text { Number of } \\
\text { samples }\end{array}$ & $\begin{array}{l}\text { Percentage } \\
(\%)\end{array}$ \\
\hline$<500$ & Desirable for Drinking & 5 & 5 & 9 & 9 \\
\hline $\begin{array}{l}500- \\
1,000\end{array}$ & $\begin{array}{l}\text { Permissible for } \\
\text { Drinking }\end{array}$ & 30 & 29 & 25 & 24 \\
\hline $\begin{array}{l}1,000- \\
3,000\end{array}$ & Useful for irrigation & 38 & 36 & 41 & 39 \\
$>3000$ & $\begin{array}{l}\text { Unfit for drinking and } \\
\text { irrigation }\end{array}$ & 32 & 30 & 29 & 28 \\
\hline
\end{tabular}

According to Freeze and Cherry (Table.3), TDS-based groundwater classification analysis of freshwater before and after the monsoon is 33-36\% freshwater, and brackish water before and after the monsoon is $63-59 \%$ of the season. The high TDS is due to the presence of large amounts of sodium and chloride ions. The high concentration of TDS in groundwater samples is due to the leaching of salt from the soil, and domestic sewage may also penetrate the groundwater

Table: 3 Freeze and Cherry classification of Groundwater based on TDS (mg/l)

\begin{tabular}{|llllll|}
\hline & \multicolumn{2}{l|}{ Pre-monsoon (2016) } & & \multicolumn{2}{l|}{ Post-monsoon (2017) } \\
\hline TDS $(\mathrm{mg} / \mathrm{l})$ & $\begin{array}{l}\text { Water } \\
\text { Type }\end{array}$ & $\begin{array}{l}\text { Number of } \\
\text { samples }\end{array}$ & Percentage & $\begin{array}{l}\text { Number of } \\
\text { Samples }\end{array}$ & Percentage \\
\hline$<1,000$ & Fresh & 35 & 33 & 38 & 36 \\
\hline $1,000-10,000$ & Brackish & 66 & 63 & 62 & 59 \\
10,000 & Saline & 4 & 4 & 5 & 5 \\
$-1,00,000$ & Brine & 0 & 0 & 0 & 0 \\
\hline$>1,00,000$ & D & & 0 & & 0 \\
\hline
\end{tabular}

Total Hardness (TH) depends on the calcium and magnesium content of water is calculated by the flowing Eq. (2). The maximum and minimum value of TH in the water samples is $140 \mathrm{mg} / \mathrm{l}$ to $15935 \mathrm{mg} / \mathrm{l}$ with an average of $1258 \mathrm{mg} / \mathrm{l}$ in the pre-monsoon and $99 \mathrm{mg} / \mathrm{l}$ to $19969 \mathrm{mg} /$ in the post-monsoon 
season. As per the WHO standards, the desirable limit of $\mathrm{TH}$ is $100 \mathrm{mg} / \mathrm{l}$ whereas the maximum permissible level is $300 \mathrm{mg} / \mathrm{l}$.

TH was above the maximum permissible limit of $300 \mathrm{mg} / \mathrm{l}$ in 87 groundwater samples are considered as very hard type water (Table. 4), $16 \%$ of the groundwater samples fell under hard type water in premonsoon season and $83 \%$ of groundwater has very hard type water in post-monsoon, as well as $1 \%$ and $20 \%$ are moderately high, hard type in post-monsoon season shown in fig: 6 and fig: 7

Table: 4 Classification of groundwater based on TH (mg/l)

\begin{tabular}{|llllll|}
\hline & \multicolumn{2}{l}{ Pre-monsoon (2016) } & & \multicolumn{2}{l|}{ Post-monsoon (2017) } \\
\hline $\begin{array}{l}\text { Total Hardness } \\
(\mathrm{mg} / \mathrm{l})\end{array}$ & $\begin{array}{l}\text { Type of } \\
\text { water }\end{array}$ & $\begin{array}{l}\text { Number of } \\
\text { samples }\end{array}$ & $\begin{array}{l}\text { Percentage } \\
(\%)\end{array}$ & $\begin{array}{l}\text { Number of } \\
\text { samples }\end{array}$ & $\begin{array}{l}\text { Percentage } \\
(\%)\end{array}$ \\
\hline$<75$ & Soft & 0 & 0.0 & 0 & 0.0 \\
\hline $75-150$ & $\begin{array}{l}\text { Moderately } \\
\text { high }\end{array}$ & 1 & 1.0 & 1 & 1.0 \\
\hline $150-300$ & Hard & 17 & 16.2 & 20 & 19.2 \\
\hline$>300$ & Very Hard & 87 & 82.9 & 83 & 79.8 \\
\hline
\end{tabular}

The Electrical Conductivity (EC) value ranges from $400 \mu \mathrm{S} / \mathrm{cm}$ to $29000 \mu \mathrm{S} / \mathrm{cm}$ (pre-monsoon) and 400 $\mu \mathrm{S} / \mathrm{cm}$ to $45000 \mu \mathrm{S} / \mathrm{cm}$ (post-monsoon) with an average of $4018 \mu \mathrm{S} / \mathrm{cm}$ and $4451 \mu \mathrm{S} / \mathrm{cm}$ during premonsoon and,post-monsoon season respectively is shown in Fig. 8 and Fig. 9. The high EC values in the Krishna area appear pre and post the monsoon. It is the measurement of all soluble salts in the sample, which is the most important water quality standard for crop productivity, that is, water and salt damage. The main effect of high EC water on crop productivity is that plants cannot compete with ions in soil solutions for water. Even though the soil may show wet, because plants can only transpire pure water, useable plant water in the soil solution decreases significantly as EC increases. The amount of water transpired through a crop was directly related to yield. Therefore, irrigation water with high EC reduces yield potential. The present study indicated that overall the water quality was medium to high in the EC category.

The Carbonate $\left(\mathrm{CO}_{3}\right)$ value is a maximum of $48 \mathrm{mg} / \mathrm{l}$ in pre-monsoon with an average of $6.5 \mathrm{mg} / \mathrm{l}$. The Bicarbonate $\left(\mathrm{HCO}_{3}\right)$ value ranges from $73 \mathrm{mg} / \mathrm{l}$ to $1159 \mathrm{mg} / \mathrm{l}$ in pre-monsoon and $97 \mathrm{mg} / \mathrm{l}$ to $2293 \mathrm{mg} / \mathrm{l}$ during the post-monsoon period with an average of $458 \mathrm{mg} / \mathrm{l}$ and $947 \mathrm{mg} / \mathrm{l}$. The high $\mathrm{HCO}_{3}$ values towards the North-East direction are seen in the post-monsoon period whereas isolated distribution is seen in the pre-monsoon season. The Chloride $\left(\mathrm{Cl}^{-}\right)$value ranges from $56.7 \mathrm{mg} / \mathrm{l}$ to $8820 \mathrm{mg} / \mathrm{l}$ in premonsoon and $71.0 \mathrm{mg} / \mathrm{l}$ to $11928.0 \mathrm{mg} / \mathrm{l}$ during the post-monsoon period with an average of 947.5 and $957.6 \mathrm{mg} / \mathrm{l}$ during the pre-monsoon and post-monsoon respectively. The high chloride values are shown 
in Nizampatnam Mandal in a post-monsoon period whereas a northward trend is seen in pre-monsoon (Fig. 10 and Fig. 11)

The Calcium $\left(\mathrm{Ca}^{2+}\right)$ value ranges from $20 \mathrm{mg} / \mathrm{l}$ to $528 \mathrm{mg} / \mathrm{l}$ in pre-monsoon and $32 \mathrm{mg} / \mathrm{l}$ to $464 \mathrm{mg} / \mathrm{l}$ during post-monsoon period with an average of $99.4 \mathrm{mg} / \mathrm{l}$ and $122 \mathrm{mg} / \mathrm{l}$ during pre-monsoon and postmonsoon respectively. The high calcium values are seen near coastal areas towards the stream mouth area in both pre-monsoon and post-monsoon periods. The Magnesium $\left(\mathrm{Mg}^{2+}\right)$ value ranges from $4.8 \mathrm{mg} / \mathrm{l}$ to $651 \mathrm{mg} / \mathrm{l}$ in pre-monsoon, and $4.8 \mathrm{mg} / \mathrm{l}$ to $849.6 \mathrm{mg} / \mathrm{l}$ during the post-monsoon period with an average of 80.6 and $98.2 \mathrm{mg} / \mathrm{l}$ during pre-monsoon and post-monsoon respectively. The postmonsoon period high Magnesium values are seen in Machilipatnam Mandal, Sakthinethipalle river mouth area, Uppalaguptam, and Nizampatnam near the coastal region and the north parts of the Godavari area where low magnesium occur.

The Sulphate $\left(\mathrm{SO}_{4}\right)$ value ranges from $2.4 \mathrm{mg} / \mathrm{l}$ to $224.8 \mathrm{mg} / \mathrm{l}$ (pre-monsoon) and $2 \mathrm{mg} / \mathrm{l}$ to $43.7 \mathrm{mg} / \mathrm{l}$ (post-monsoon) with an average of 62.3 and $10.3 \mathrm{mg} / \mathrm{l}$. The low $\mathrm{SO}_{4}$ values are seen entire study area in the post-monsoon period, whereas this trend is seen isolated in pre-monsoon. The Sodium $\left(\mathrm{Na}^{+}\right)$value ranges from $40.8 \mathrm{mg} / \mathrm{l}$ to $5006.8 \mathrm{mg} / \mathrm{l}$ (pre-monsoon) and $9.3 \mathrm{mg} / \mathrm{l}$ to $8285 \mathrm{mg} / \mathrm{l}$ (post-monsoon) with an average of $634 \mathrm{mg} / \mathrm{l}$ and $670.8 \mathrm{mg} / \mathrm{l}$. The Potassium $\left(\mathrm{K}^{+}\right)$value ranges from $1.6 \mathrm{mg} / \mathrm{l}$ to $443 \mathrm{mg} / \mathrm{l}$ (premonsoon) and $1.9 \mathrm{mg} / \mathrm{l}$ to $712.2 \mathrm{mg} / \mathrm{l}$ (post-monsoon) with an average of $60.4 \mathrm{mg} / \mathrm{l}$ and $83.1 \mathrm{mg} / \mathrm{l}$ during pre-monsoon and post-monsoon respectively. In pre-monsoon high potassium values are seen in Machilipatnam mandal and it is slightly varying in post-monsoon season.

\subsection{Piper Trilinear Diagram:}

The concentration of major anions and cations can be plotted on the Piper Trilinear graph to understand the geochemical evolution of groundwater. Use AquaChem 2014 software to transpose different groundwater chemical evolution paths and freshwater composition fields (Fig. 12) onto Piper diagrams. Piper diagram is a combination of anion and cation triangles on a common baseline. The diamonds between them are used to characterize different types of water.

The graphical illustration of the ion signature helps to reveal the main ions that control water chemistry. Piper divides water into four types by placing water near the four corners of the diamond. The Water plotted at the top of the diamond is considered as high with $\mathrm{Ca}^{2+}+\mathrm{Mg}^{2+}$ and $\mathrm{Cl}^{-}+\mathrm{SO}_{4}{ }^{-2}$, which is the area of permanent hardness. The water plot near the right side corner is rich in $\mathrm{Ca}^{2+}+\mathrm{Mg}^{2+}$ this water region is temporary hardness. The water plot at the lower corner is composed of alkali carbonates $\left(\mathrm{Na}^{+}+\mathrm{K}^{+}\right.$and $\left.\mathrm{HCO}_{3}{ }^{-}+\mathrm{CO}_{3}{ }^{-2}\right)$. The water near the left-hand side may be Saline water $\left(\mathrm{Na}^{+}+\mathrm{K}^{+}\right.$and $\left.\mathrm{Cl}^{-}+\mathrm{SO}_{4}{ }^{-2}\right)$. It has been observed in Piper's Diagram that the nature of groundwater exists in the $\mathrm{Na}^{+}-\mathrm{Cl}^{-}$type study area. Therefore, the Piper diagram can not only identify the nature of water samples but also reveal the relationship between water samples. It is possible to predict and classify geological units and chemically similar water, and then to analyze the trend and flow path of water chemical analysis. In pre-monsoon 
piper diagram can not only identify the nature of water samples but also reveal the relationship between water samples. It is possible to predict and classify geological units and chemically similar water, and then to analyze the trend and flow path of water chemical analysis. The diagram shows whether the salinity is derived solely from mixing with seawater.

\section{Common Indicators Of Sea Water Intrusion (Swi) 6.1 Ca/Mg Ratio}

$\mathrm{A}$ high $\mathrm{Ca} / \mathrm{Mg}$ ratio may indicate that the brine is contaminated because the magnesium content in seawater is much higher than calcium. Therefore, the $\mathrm{Ca} / \mathrm{Mg}$ ratio $(>1)$ is regarded as a parameter to determine seawater contamination. According to the $\mathrm{Ca} / \mathrm{Mg}$ ratio, many samples in the study area showed a higher $\mathrm{Ca} / \mathrm{Mg}$ ratio. Figure 13 shows that the calcium and magnesium contents in the premonsoon season are higher than in the post-monsoon season

\section{$6.2 \mathrm{Cl} /\left(\mathrm{CO}_{3}+\mathrm{HCO}_{3}\right)$ Ratio}

In the seawater, $\mathrm{Cl}^{-}$is the dominant ion and it is only available in small quantities in groundwater, while $\mathrm{HCO}_{3}$ that is available in large quantities in groundwater occurs only in very small quantities in seawater. $\mathrm{The} \mathrm{Cl} /\left(\mathrm{CO}_{3}+\mathrm{HCO}_{3}\right)$ known as Simpson's ratio is important as evidence for seawater intrusion into the freshwater aquifer. The $\mathrm{Cl}^{-} /\left(\mathrm{CO}_{3}+\mathrm{HCO}_{3}\right)$ ratio was used as a criterion to evaluate the saltwater intrusion. The Chloride is the dominant ion of ocean water and normally occurs in only a small amount in groundwater while $\mathrm{HCO}_{3}$ is usually the most abundant negative ion in groundwater, but it occurs in only minor amounts in seawater.

There is $14 \%$ fresh groundwater in the pre-monsoon season with $<0.5$ value. In pre-monsoon majority of the area shows slightly contaminated groundwater with a value of $0.5-1.30$ and $22 \%$ be moderately contaminated groundwater, $12 \%$ waters with injuriously contaminated, $8 \%$ highly contaminated, and $1 \%$ of water severely contaminated groundwater. In the Post-monsoon season, there is $62 \%$ fresh groundwater. The majority of the area shows $43 \%$ slightly contaminated groundwater, moderately contaminated groundwater is $9 \%$, injuriously contaminated groundwater is $4 \%$ and $3 \%$ is highly contaminated groundwater in the study area according to this ratio details are shown in Fig. 14

\section{$6.3 \mathrm{Na} / \mathrm{Cl}$ Ratio}

The $\mathrm{Na} / \mathrm{Cl}$ ratio of saltwater intrusion is usually lower than the ocean values (i.e., $<0.86$, molar ratio). On the other hand, high (more than 1 ) $\mathrm{Na} / \mathrm{Cl}$ ratios, typically characterize anthropogenic sources like domestic waters. Thus low $\mathrm{Na} / \mathrm{Cl}$ ratios combined with other geological parameters can foretell the arrival of saltwater intrusion. According to the $\mathrm{Na} / \mathrm{Cl}$ ratio, in the pre-monsoon and post-monsoon seasons, approximately $71 \%$ and $60 \%$ of the study area was contaminated by the ocean (Fig. 15), and the remaining areas were $29 \%$ and $40 \%$ contaminated due to human pollution. Domestic sewage may be 
controlled by water-rock interaction. The combination of high $\mathrm{Na} / \mathrm{Cl}$ molar ratio and high salinity value can prove that seawater intrusion may be the main reason for salinization near the coastline.

\subsection{Seawater Mixing Index (SMI)}

The seawater mixing index was developed by Park et al. (2005) to identify seawater intrusion based on the concentration of magnesium, sodium, chlorine, and sulfate. Mondal and Singh (2011) revised this to understand the salinization process and SMI stated that it would quantitatively evaluate the mixed grade of brine in residential water. The seawater mixing index of groundwater aquifers is a quantitative assessment used to identify seawater mixing based on four major ions such as $\mathrm{Na}^{+}, \mathrm{Mg}^{2+}, \mathrm{Cl}^{-}$, and $\mathrm{SO}_{4}{ }^{2-}$. These ions are highly used in the study of saltwater and groundwater mixing index. SMI is calculated by the following equation, where $a, b, c$ and $d$ are $\mathrm{Na}+(a=0.31), \mathrm{Mg}^{2+}(b=0.04), \mathrm{Cl}^{-}(\mathrm{c}=0.57)$ and $\mathrm{SO}_{4}{ }^{2-}(\mathrm{d}=0.08)$ (Park et al. (2005) and the concentration of ions. A calculated SMI value greater than 1 will indicate the effect of mixing seawater and freshwater.

$\mathrm{SMI}=a X \frac{C_{N a}}{T_{N a}}+b X \frac{\mathrm{C}_{\mathrm{Mg}}}{T_{M g}}+c X \frac{\mathrm{C}_{\mathrm{Cl}}}{T_{C l}}+d X \frac{\mathrm{C}_{\mathrm{So} 4}}{T_{S o 4}}$

$\mathrm{C}=$ Concentration of groundwater $(\mathrm{mg} / \mathrm{l})$

$\mathrm{T}=$ Regional threshold values

Cumulative probability (CP) curves can be used to estimate seawater mixing and thresholds for selected parameters (such as $\mathrm{Na}^{+}, \mathrm{Mg}^{2+}, \mathrm{Cl}^{-}$and $\mathrm{SO}_{4}{ }^{2-}$ ), which exhibit a log-normal density distribution. For the influence of the mixing of seawater and freshwater aquifers, the cumulative probability of the above parameters at the intersection of regional thresholds can be considered. The $\mathrm{CP}$ considers the four main ions in groundwater chemistry with regional thresholds, such as $\mathrm{Mg}^{2+}=17 \mathrm{mg} / \mathrm{l}, \mathrm{Na}^{+}=112 \mathrm{mg} / \mathrm{l}, \mathrm{Cl}^{-}=$ $142 \mathrm{mg} / \mathrm{l}$ and $\mathrm{SO}_{4}{ }^{2-}=41 \mathrm{mg} / \mathrm{l}$ in post-monsoon season, pre-monsoon $\mathrm{Mg}^{2+}=36 \mathrm{mg} \mathrm{/l,} \mathrm{Na}^{+}=81 \mathrm{mg} / \mathrm{I}$, $\mathrm{Cl}^{-}=152 \mathrm{mg} / \mathrm{l}, \mathrm{SO}_{4}{ }^{2-}=90 \mathrm{mg} / \mathrm{l}$ area. The SMI in the post-monsoon season is between 0.4 and 72.9 and in pre-monsoon season is between 0.4 and 53.1 ; about $78 \%$ of the groundwater is post-monsoon period and about $87 \%$ of the SMI is greater than 1 pre-monsoon season.

\subsection{Integrated Groundwater Quality}

Based on the comparison of the conductivity and the concentration of $\mathrm{Na}^{+}$and $\mathrm{Cl}^{-}$with the allowable limits of BIS (2012) and WHO (1993), the quality of groundwater was evaluated. According to the recommended drinking water quality of $\mathrm{Na}^{+}, \mathrm{Cl}^{-}, \mathrm{Na}^{+} / \mathrm{Cl}^{-}$and $\mathrm{Cl}^{-} / \mathrm{HCO}_{3}{ }^{-}$, the groundwater quality is roughly divided into two categories, suitable and unsuitable (Fig. 16 and Fig. 17). In the pre-monsoon and post-monsoon seasons, groundwater in rivers (Godawari, Krishna) and other areas were affected by backwaters, salt pans, and canals and was found to be unsuitable for drinking, while groundwater in other areas was suitable for drinking. There are very few locations with good portable drinking water during the pre-monsoon season. They include Mamidikuduru, Sakhinetipalle, in East Godavari district; 
near Narsapuram in West Godavari district; Avinigadda, in Krishna district, and Karlapalem Mandal in Guntur district. The significant parts of the Krishna and Godavari delta region is portable during the postmonsoon season, except Allavaram, and Sakhinetipalle in East Godavari district, Koduru in Krishna district; and Nizampatnam in Guntur district. The spatial distribution of sodium in the groundwater indicating the suitability for drinking purposes is shown in Fig. 16 and Fig. 17.

\section{Conclusion}

The groundwater hydrochemical characteristics of the Krishna and Godavari deltas indicate that seawater plays a very important role in groundwater quality/composition. In the pre-monsoon season, close to Makiripatnam, Alavaram, Sahnetipal, and many parts of the northern region, low resistivity was affected. About $71 \%$ of groundwater is $\mathrm{Na}^{+}-\mathrm{Cl}^{-}$type, the SMI concentration post-monsoon is between 0.4 and 72.9, and the SMI concentration pre-monsoon is between 0.4 and 53.1. In the present area, about $82 \%$ of freshwater chemicals with high SMI concentrations are contaminated with salt water. The premonsoon season is more suitable for drinking than the post-monsoon season. The few locations of this area were identified with seawater intrusion, due to the influence of geomorphology of the study area and salt flat. During the monsoon season, the quality of groundwater is improved due to rainfall replenishing the aquifer, which makes the freshwater level higher and reduces seawater intrusion in the delta. To overcome this situation, it is necessary to change the pumping method of coastal areas to inland areas by constructing new wells field, and effectively control the intrusion of seawater and the restoration of groundwater quality. The conclusion is that the process of controlling groundwater salinity revealed by chemical and statistical analysis is mainly related to seawater intrusion and ion exchange processes related to seawater intrusion. This research may be useful to help planners and decision-makers protect our limited groundwater resources for future generations.

\section{Declarations}

\section{Acknowledgments}

The authors express their sincere gratitude to the Chairman, APSAC for his continuous support for the research activity and saline water testing lab at Agricultural University, Bapatla; also the authors are grateful to the editor and anonymous reviewers for suggestions and comments which improved the manuscript significantly.

\section{Availability of data and materials}

All data generated or analyzed during this study are included in this article. The raw data are available from the corresponding author upon reasonable request.

\section{Competing interests}

The authors declare they have no competing interests. 


\section{Funding}

No specific funding has been received for this study from any particular agency, this research project funded by Andhra Pradesh Space Applications centre, Vijayawada for in-house project.

\section{Author contributions section}

Kannan- writing, statistical analysis, and data interpretation, fieldwork, map preparation, Appala Naidu Assist in the fieldwork. Abhrankash Kanungo - Helps in statistical analysis, methodology, M.V.Ramana Murty - Assist in re-writing, supervision, K.V.Ramana - Conceptualization, supervision.

\section{Conflicts of interest}

The authors declare that there are no conflicts of interest. The authors alsocertify that there are no ethical issues involved.

\section{References}

1. Ashraf Ali Seddiquea, Harue Masuda, Ryo Anma, Prosun Bhattacharya, Yoriko Yokooe, Yuta Shimizu (2019), Hydrogeochemical and isotopic signatures for the identification of seawater intrusion in the paleo beach aquifer of Cox's Bazar city and its surrounding area, south-east Bangladesh, journal of Groundwater for Sustainable Development, April 2019. https://doi.org/10.1016/j.gsd.2019.100215

2. Annapoorani A., Murugesan A., Ramu A. and Renganathan N.G. (2014), Hydrochemistry of Groundwater in and around Chennai, India - A Case Study, Research Journal of Chemical Sciences ISSN 2231-606X, Vol. 4(4), pp 99-106, April.

3. Anil Kumar K.S, C.P.Priju, N.B.Narasimha Prasad (2015), Study on Saline Water intrusion into the Shallow Coastal Aquifers of Periyar River Basin, Kerala using Hydrochemical and Electrical Resistivity Methods. Aquatic Procedia Volume 4. https://doi.org/10.1016/j.aqpro.2015.02.006

4. APHA (1992) Standard Methods for the Examination of Water and Wastewater. American Public Health Association, Washington, DC, USA.

5. BIS Recommendations (2005) Guidelines for drinking water quality, Volume 1.

6. J. (1999) Seawater intrusion in coastal aquifers: concepts, methods, and practices. Boston. Mass: Kluwer Academic. Book title: Seawater Intrusion in Coastal Aquifers DOI: 10.1007/978-94-017-2969-7

7. Brindha K, Paul P, Touleelor S, Somphasith D, Elango L (2016) Geochemical Characteristics and Groundwater Quality in the Vientiane Plain, Laos, Journal of Water Quality Exposure and Health, July 2016. DOI: 1007/s12403-016-0224-8

8. Chen K.P and Jiao.J. J, (2007) Seawater intrusion and aquifer freshening near the reclaimed coastal area of Shenzhen, water science \& technology, water Supply, pp137-145 DOI: 2166/ws.2007.048

9. Childs, C. (2004). Interpolating Surfaces in ArcGIS Spatial Analyst. ESRI Education Services.

Retrieved from https://www.esri.com/news/arcuser/0704/files/interpolating.pdf 
10. N.S and R.J.M.DeWiest, (1966) Hydrogeology, JohnWiley\& Sons, New York, pp 463

11. Freeze R. A and Cherry.J. A, (1979) Groundwater, Prentice-Hall, New Jersey.

12. Giuseppe Sappa and Maria Teresa Coviello (2012), Seawater Intrusion, and Salinization Processes Assessment in a Multistrata Coastal Aquifer in Italy. Journal of Water Resource and Protection, Volume 4, pp 954-967. DOI: 4236/jwarp.2012.411111

13. ISI (1983) Indian Standard Specification for Drinking Water. ISI: 10500.

14. Mondal, N. C., Singh, V. S., Puranik, S. C., Singh, V. P. (2010b). Trace element concentration in groundwater of Pesarlanka Island, Krishna Delta, India. Environmental Monitoring and Assessment, 163, 215-227.

15. Mondal CN, Singh PV, Singh S, Singh SV (2011) Hydrochemical characteristic of the coastal aquifer from Tuticorin, Tamil Nadu, India. Environ Monit Assess 175:531-550

16. Magesh, N. S., Chandrasekar, N., \& Elango, L. (2016). Occurrence and distribution of fluoride in the groundwater of the Tamiraparani River basin, South India: A geostatistical modeling approach. Environmental Earth Sciences, 75(23), 1483.

17. Narayan, S.M. and Natarajan, K., (1993) Seawater-Freshwater interface studies in coastal areas with special reference to Tamilnadu. International Proceedings volume on workshop on artificial recharge of groundwater in coastal aquifers, CGWB,27-28 March,

18. Nair IS, Parimala Renganayaki S, Elango L (2013) Identification of seawater intrusion by $\mathrm{Cl} / \mathrm{Br}$ ratio and mitigation through managed aquifer recharge in aquifers North of Chennai, India. J Groundw Res 2:19

19. Rajib Paul, K. Brindha, G. Gowrisankar, Mou Leong Tan, Mahesh Kumar Singh (2019) Identification of hydrogeochemical processes controlling groundwater quality in Tripura, Northeast India using evaluation indices, GIS, and multivariate statistical methods. Environmental Earth Sciences (2019) 78:470 https://doi.org/10.1007/s12665-019-8479-6

20. Pujari P.R., and Soni, A.K., (2009) Seawater intrusion studies near Kovaya limestone mine, Saurashtra coast, Indian journal of Environ Monitoring Assess. 154:93-109. https://doi.org/10.1007/s10661008-0380-9

21. Piper, A.M.(1944) A Graphical Procedure in the Geochemical Interpretation of Water Analysis. Transactions, American Geophysical Union, 25, 914-923.

http://dx.doi.org/10.1029/TR025i006p00914

22. Park SC, Yun ST, Chae GT, Yoo IS, Shin KS, Heo CH, Lee SK (2005) Regional hydrochemical study on salinization of coastal aquifers, a western coastal area of South Korea. J Hydrol 313(3-4):182-194. https://doi.org/10.1016/j.jhydrol.2005.03.001

23. Richter, B. C., \& Kreitler, C. W. (1993). Geochemical techniques for identifying sources of groundwater salinization. Boca Raton: CRC Press.

24. Saxena, V. K. Singh, V. S., Mondal, N. C., Jain, S. C. 2003. Use of chemical parameters to delineation fresh groundwater resources in Potharlanka Island, India. Environmental Geology. 44(5), 516-521. 
25. Saha D.K, Choudhury K (2005). Saline Water Contamination of the Aquifer Zones of Eastern Kolkata, J. Ind. Geophys. Union, Vol.9, No.4, pp.241-247

26. Sreedevi, P.D, (2004) Groundwater Quality of Pageru River Basin, Cuddapah District, Andhra Pradesh. Journal of Geological Society of India, 64, 619-636.

27. Sudhakar, A. and Narsimha, A. (2013), Suitability and Assessment of Groundwater for Irrigation Purpose: A Case Study of Kushaiguda Area, Ranga Reddy District, Andhra Pradesh, India. Advances in Applied Science Research,75 https://www.imedpub.com/articles

28. Subba Rao N, Saroja Nirmala. I, K. Suryanarayana (2005), Groundwater Quality in a coastal area: A case study from Andhra Pradesh, India

29. L, Fidelibus M.D, Sappa. G and Coviello.M. T, (2008) Evolution of seawater intrusion in coastal aquifers of Pontina Plain, $20^{\text {th }}$ Salt Water Intrusion Meeting, 278-281. Doi:10.3390/w10020143

30. Vasanthavigar M., Srinivasamoorthy K., Vijayaragavan K., Rajiv Ganthi, Chidambaram S., Anandhan, P., Manivannan, R. and Vasudevan, S., (2010) Application of Water Quality Index for Groundwater Quality Assessment, Thirumanimuttar Sub-Basin, Tamilnadu, India. Environmental Monitoring Assessment, pp595- 609. https://doi.org/10.1007/s10661-009-1302-1

31. S (2001) Hydrogeology and geochemical characterization of groundwater with special emphasis on agricultural development in Vaniyar sub-basin, Ponnaiyar river, Tamilnadu, International Journal of Recent Scientific Research Vol.1, Issue-12, pp.213-221, December,

32. WHO, Guidelines for drinking water quality, Vol 1, Recommendations, , Geneva, 2nd edition, 130 (1993)

\section{Figures}




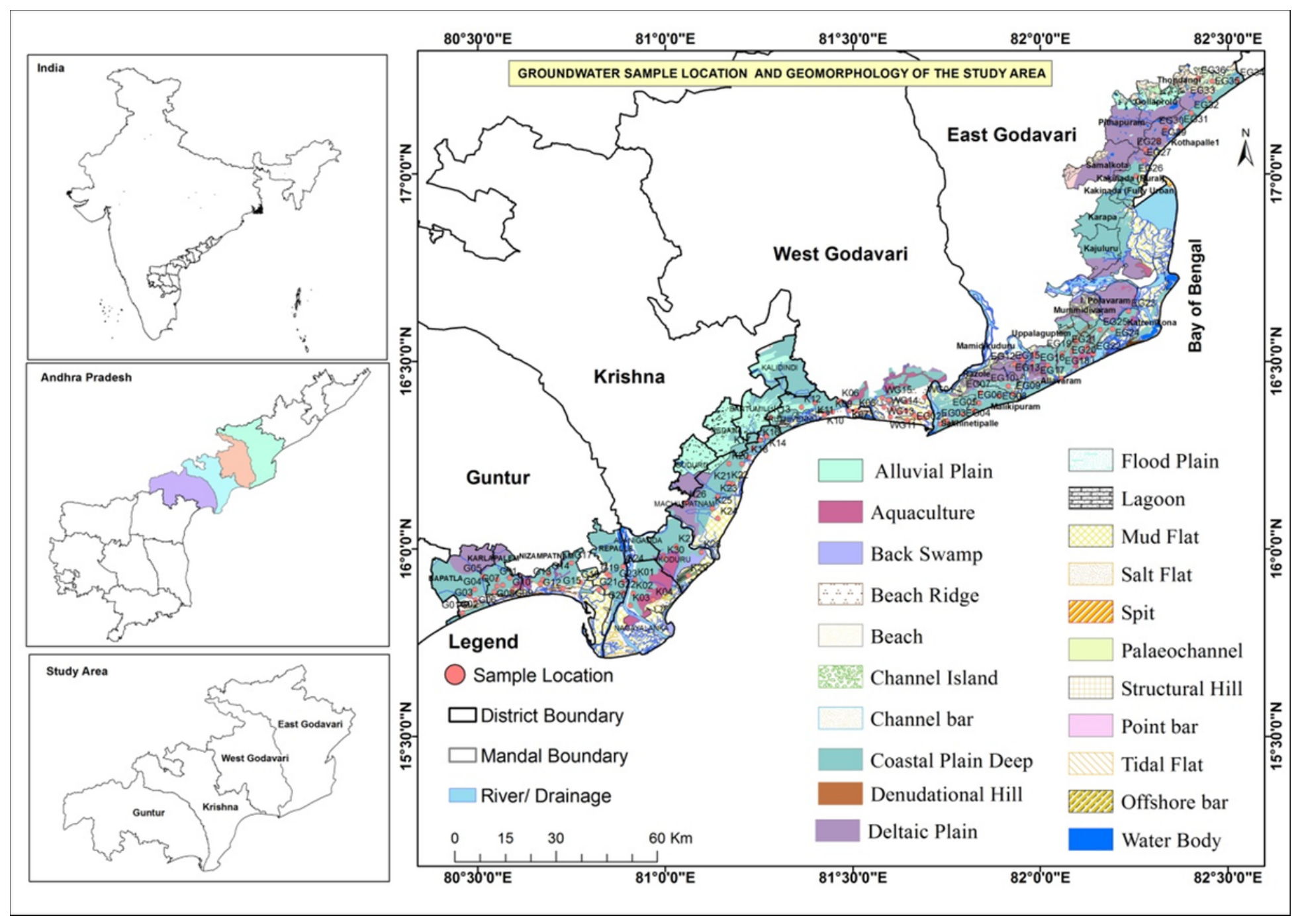

\section{Figure 1}

Study Area of Krishna - Godavari Delta Region Note: The designations employed and the presentation of the material on this map do not imply the expression of any opinion whatsoever on the part of Research Square concerning the legal status of any country, territory, city or area or of its authorities, or concerning the delimitation of its frontiers or boundaries. This map has been provided by the authors. 


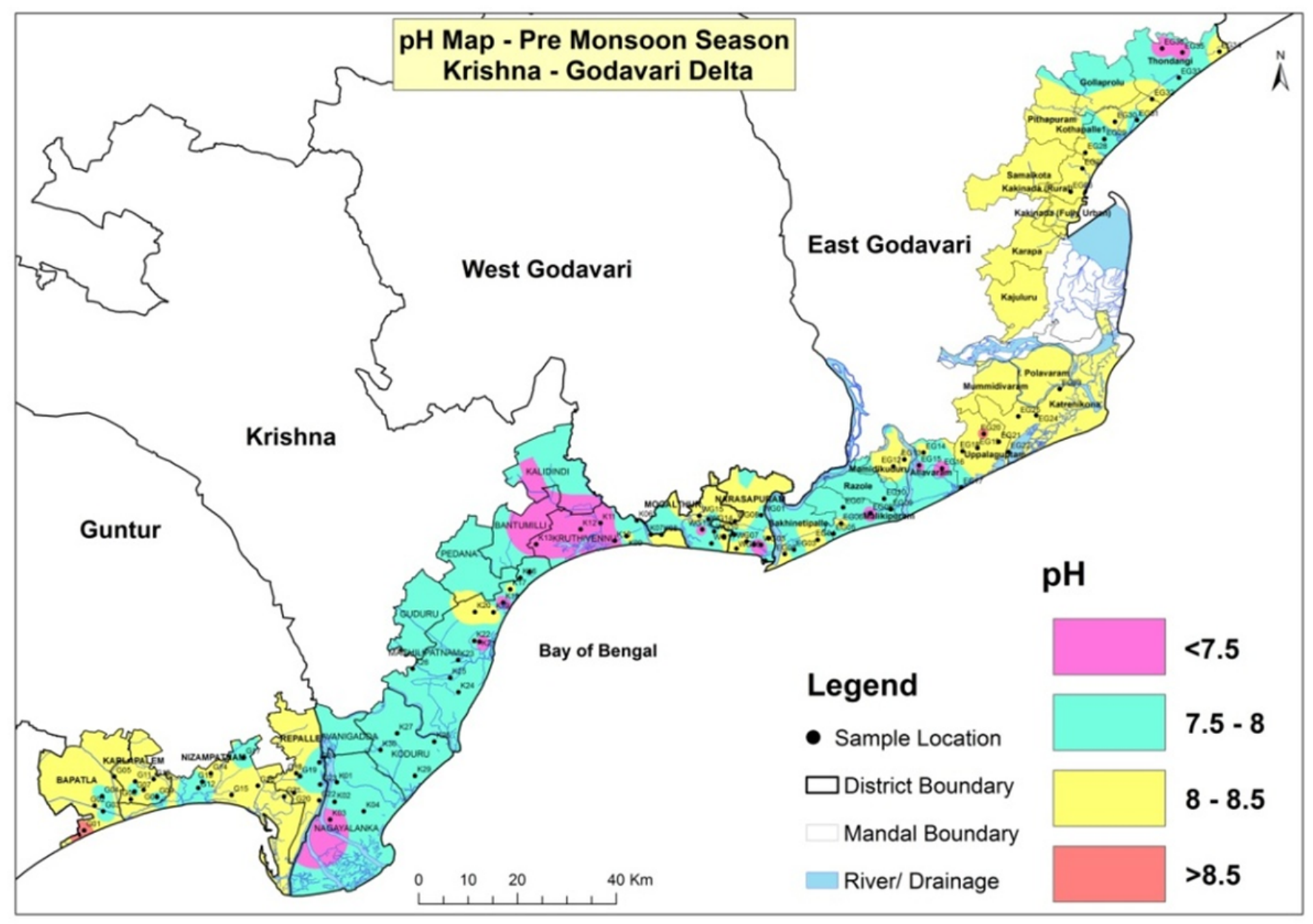

Figure 2

$\mathrm{pH}$ map pre-monsoon season Note: The designations employed and the presentation of the material on this map do not imply the expression of any opinion whatsoever on the part of Research Square concerning the legal status of any country, territory, city or area or of its authorities, or concerning the delimitation of its frontiers or boundaries. This map has been provided by the authors. 


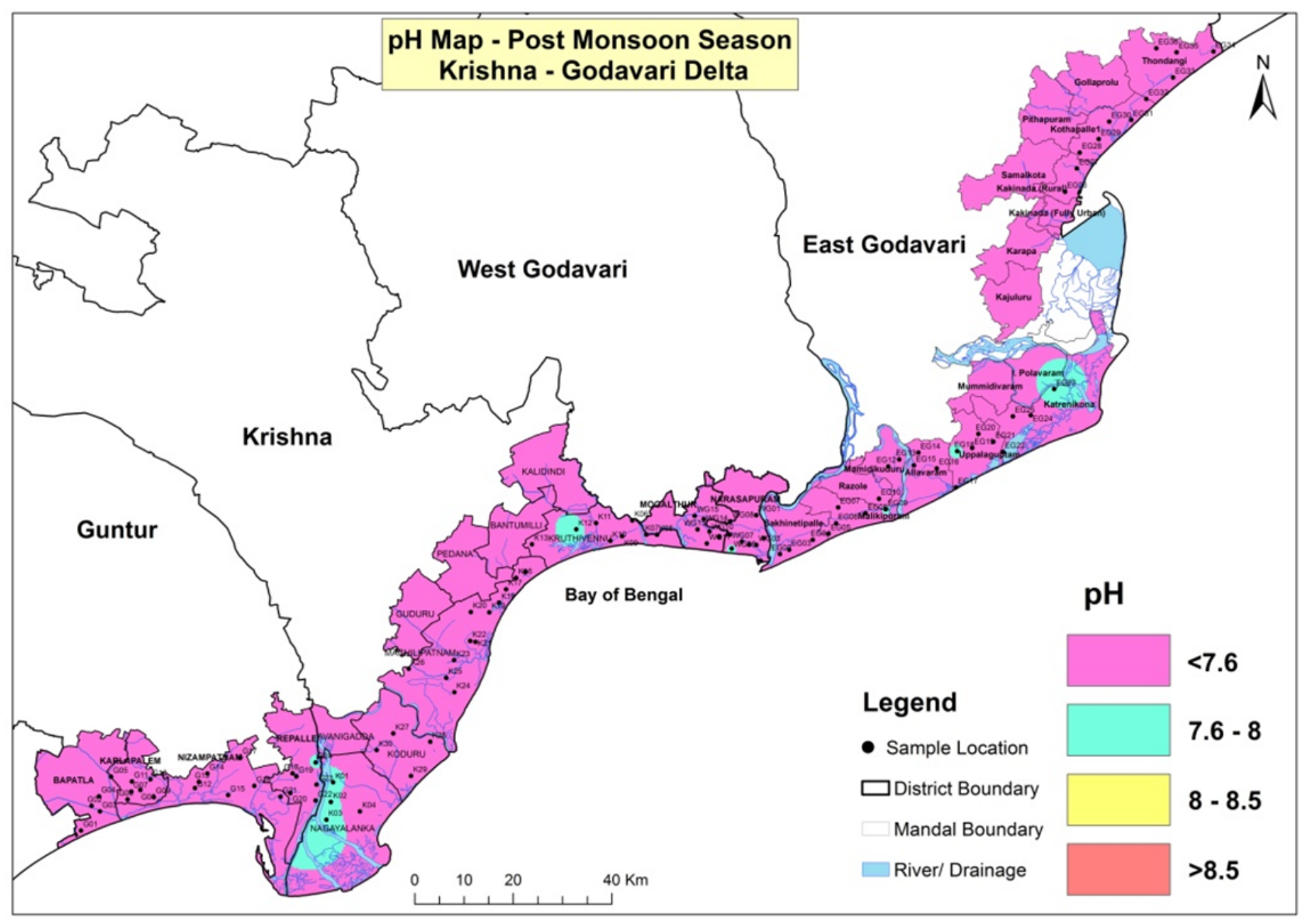

Figure 3

$\mathrm{pH}$ map post-monsoon season Note: The designations employed and the presentation of the material on this map do not imply the expression of any opinion whatsoever on the part of Research Square concerning the legal status of any country, territory, city or area or of its authorities, or concerning the delimitation of its frontiers or boundaries. This map has been provided by the authors. 


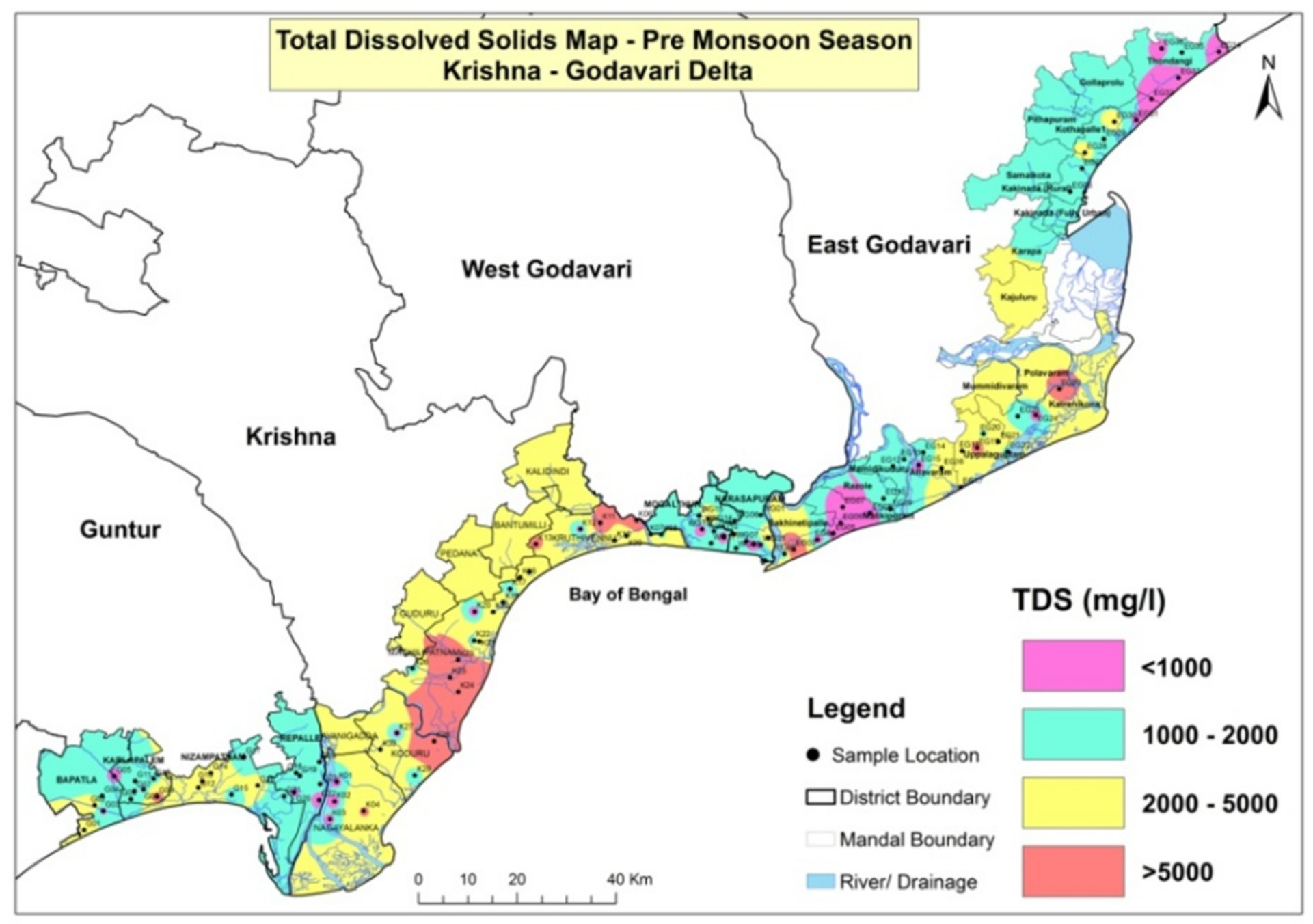

Figure 4

Total Dissolved Solid map for pre-monsoon season Note: The designations employed and the presentation of the material on this map do not imply the expression of any opinion whatsoever on the part of Research Square concerning the legal status of any country, territory, city or area or of its authorities, or concerning the delimitation of its frontiers or boundaries. This map has been provided by the authors. 


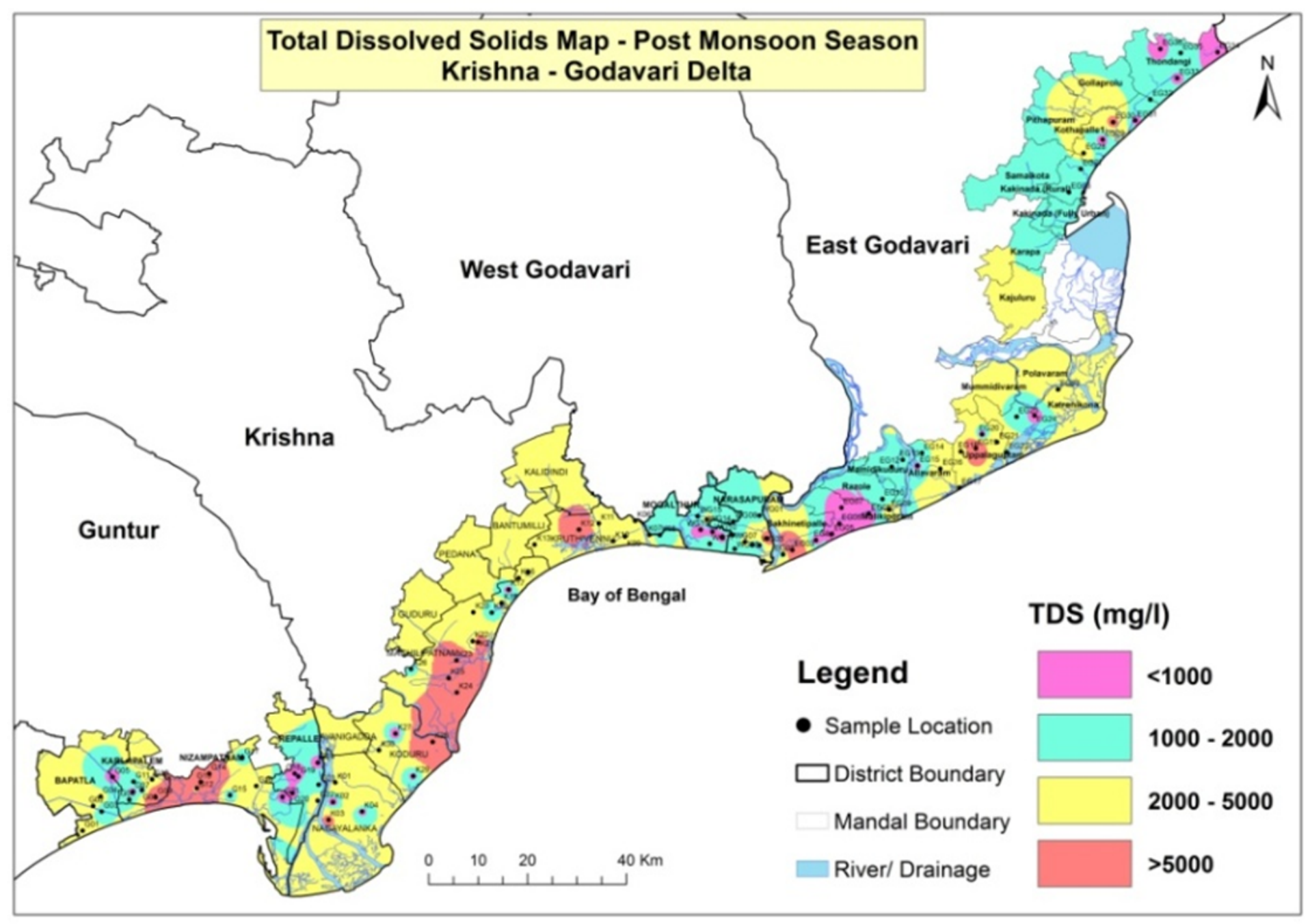

Figure 5

Total Dissolved Solid map for post-monsoon season Note: The designations employed and the presentation of the material on this map do not imply the expression of any opinion whatsoever on the part of Research Square concerning the legal status of any country, territory, city or area or of its authorities, or concerning the delimitation of its frontiers or boundaries. This map has been provided by the authors. 


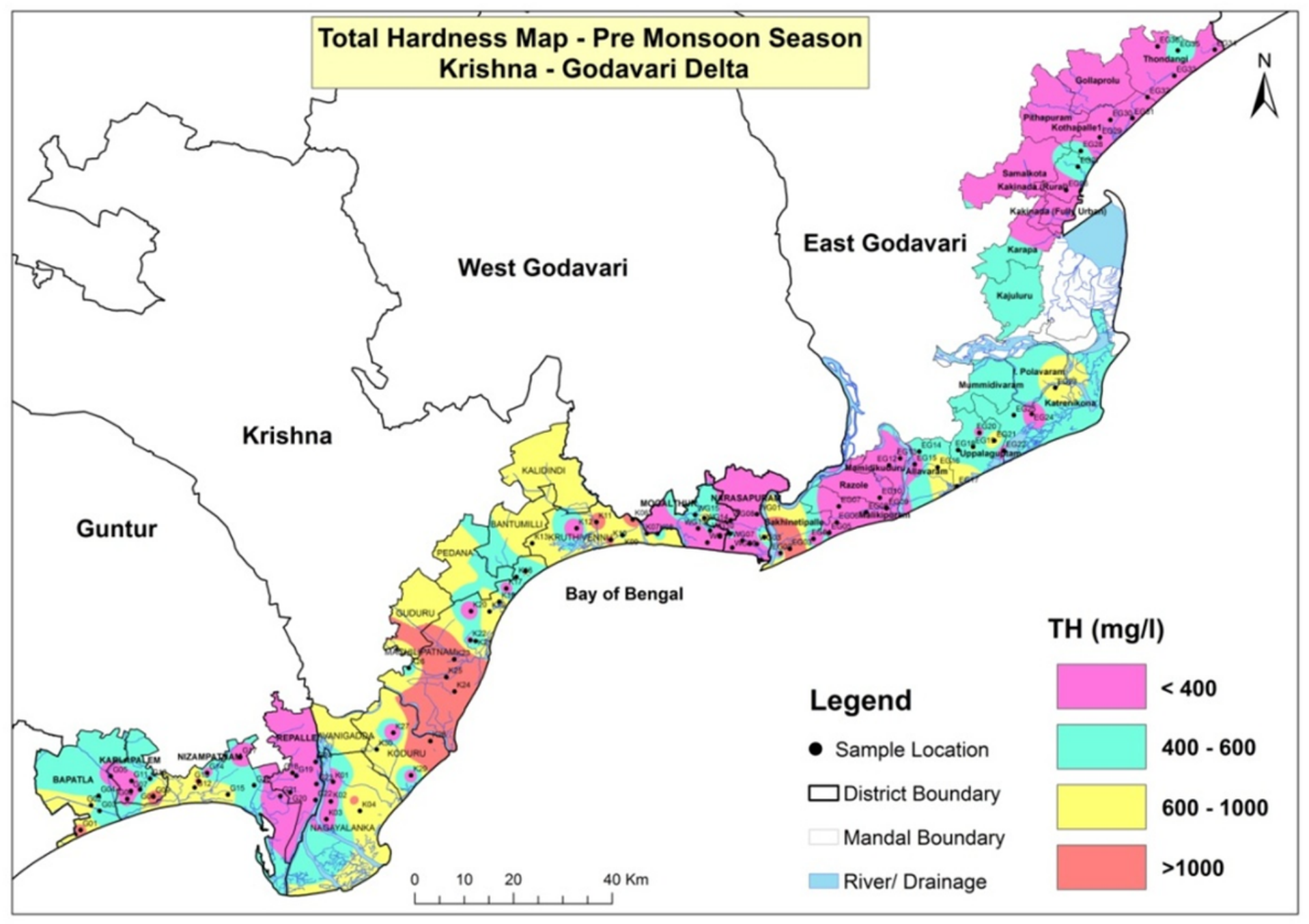

Figure 6

Total Hardness map for pre-monsoon season Note: The designations employed and the presentation of the material on this map do not imply the expression of any opinion whatsoever on the part of Research Square concerning the legal status of any country, territory, city or area or of its authorities, or concerning the delimitation of its frontiers or boundaries. This map has been provided by the authors. 


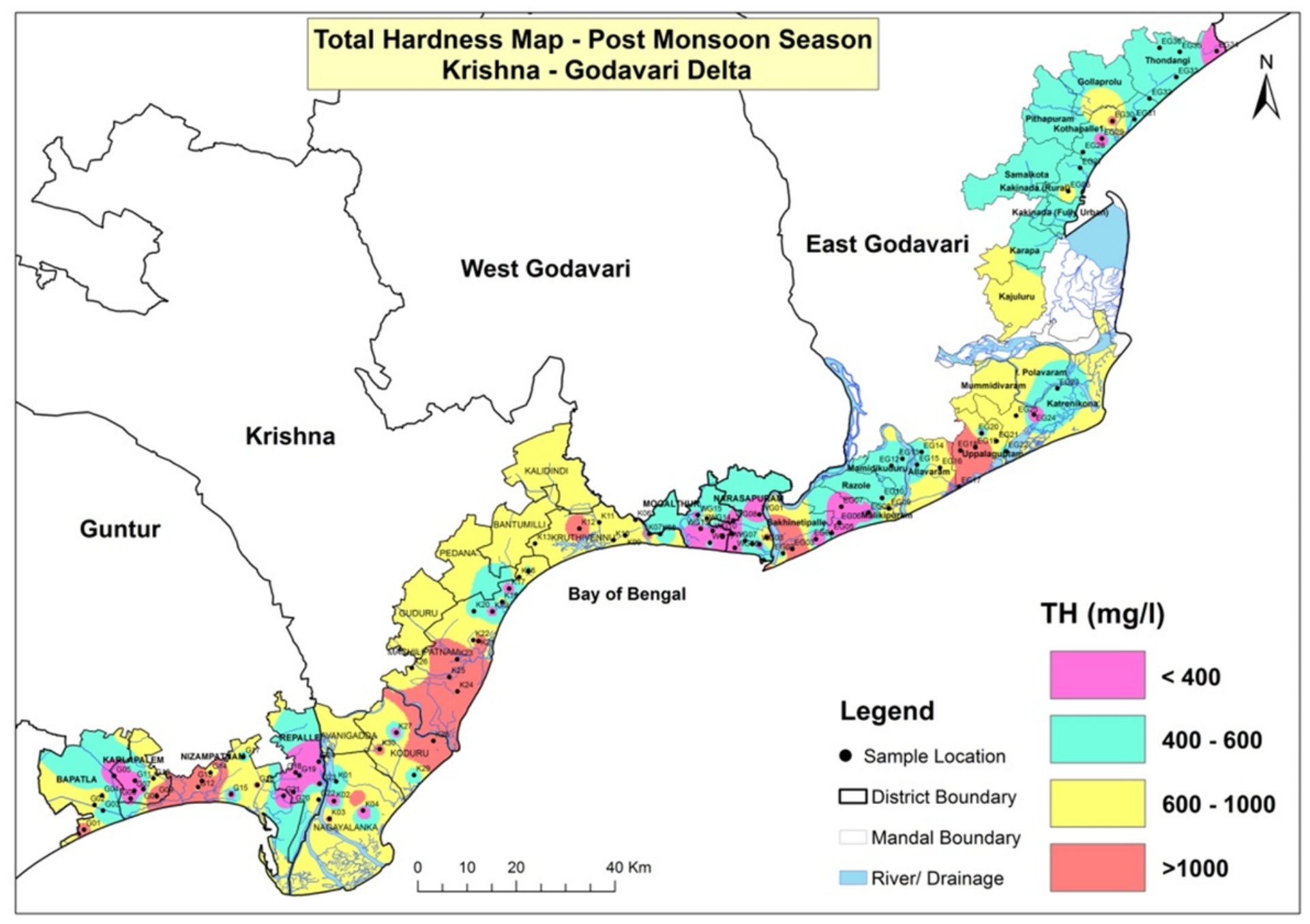

Figure 7

Total Hardness map for post-monsoon season Note: The designations employed and the presentation of the material on this map do not imply the expression of any opinion whatsoever on the part of Research Square concerning the legal status of any country, territory, city or area or of its authorities, or concerning the delimitation of its frontiers or boundaries. This map has been provided by the authors. 


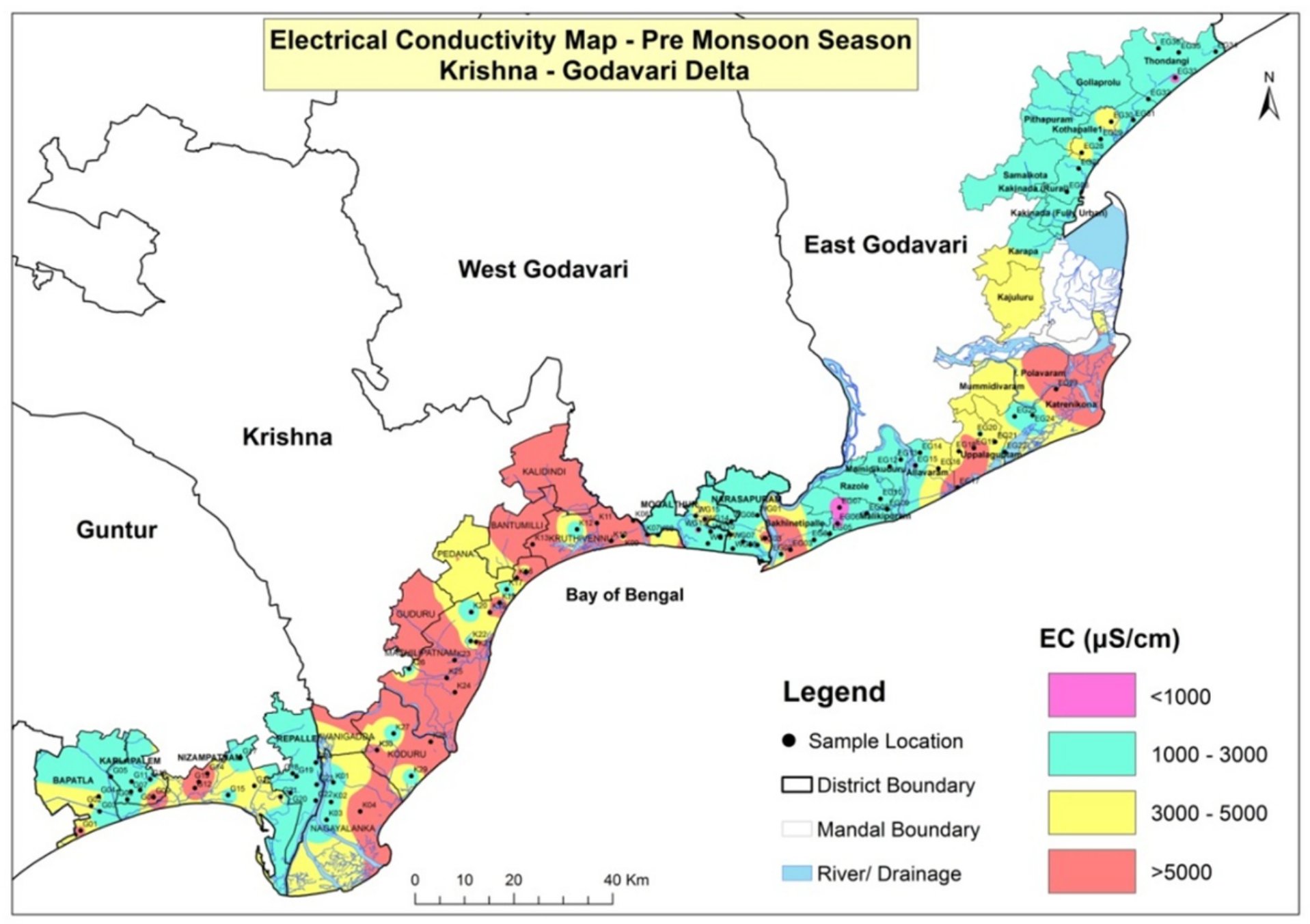

\section{Figure 8}

Electrical Conductivity map for pre-monsoon season Note: The designations employed and the presentation of the material on this map do not imply the expression of any opinion whatsoever on the part of Research Square concerning the legal status of any country, territory, city or area or of its authorities, or concerning the delimitation of its frontiers or boundaries. This map has been provided by the authors. 


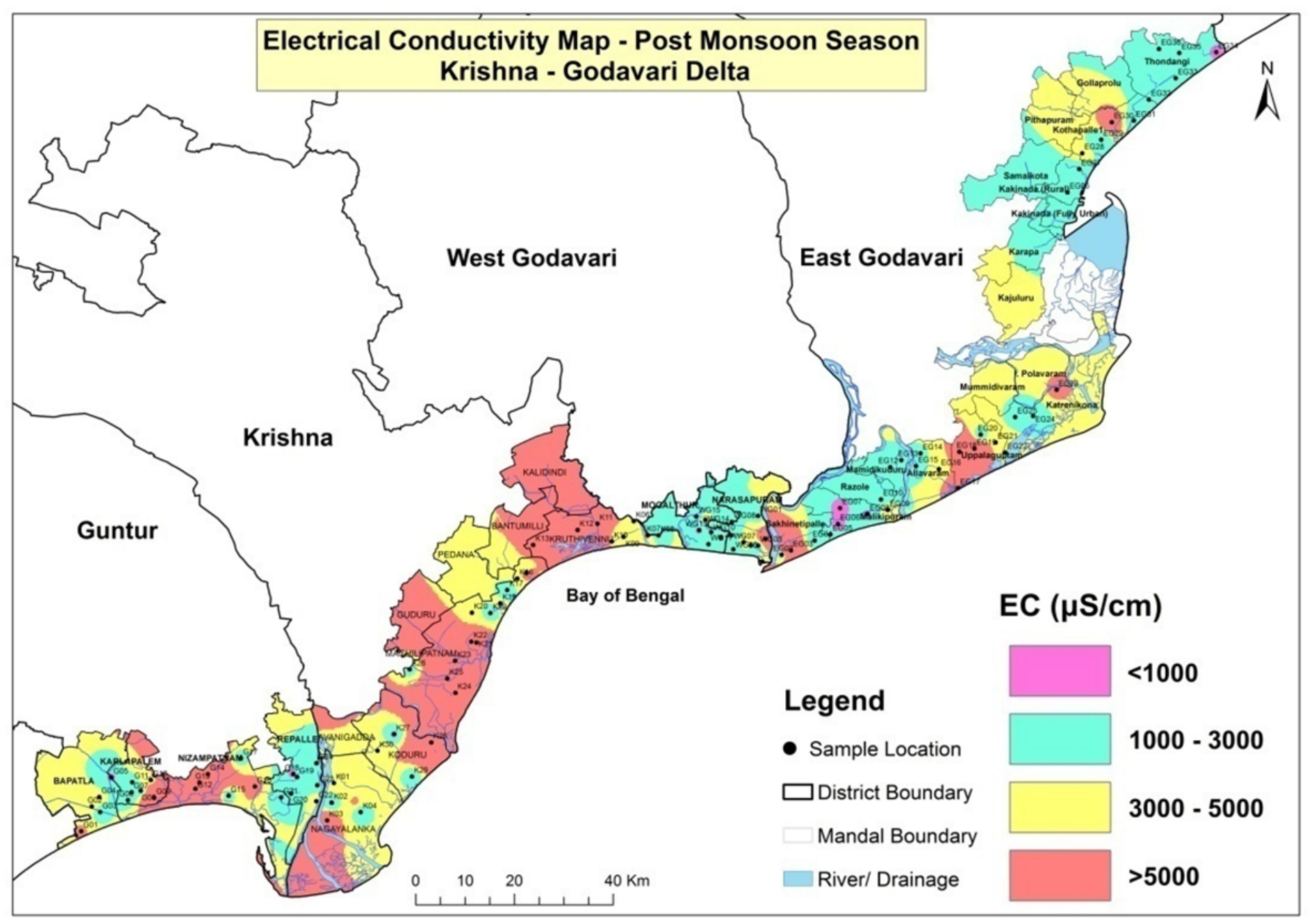

Figure 9

Electrical Conductivity map for post-monsoon season Note: The designations employed and the presentation of the material on this map do not imply the expression of any opinion whatsoever on the part of Research Square concerning the legal status of any country, territory, city or area or of its authorities, or concerning the delimitation of its frontiers or boundaries. This map has been provided by the authors. 


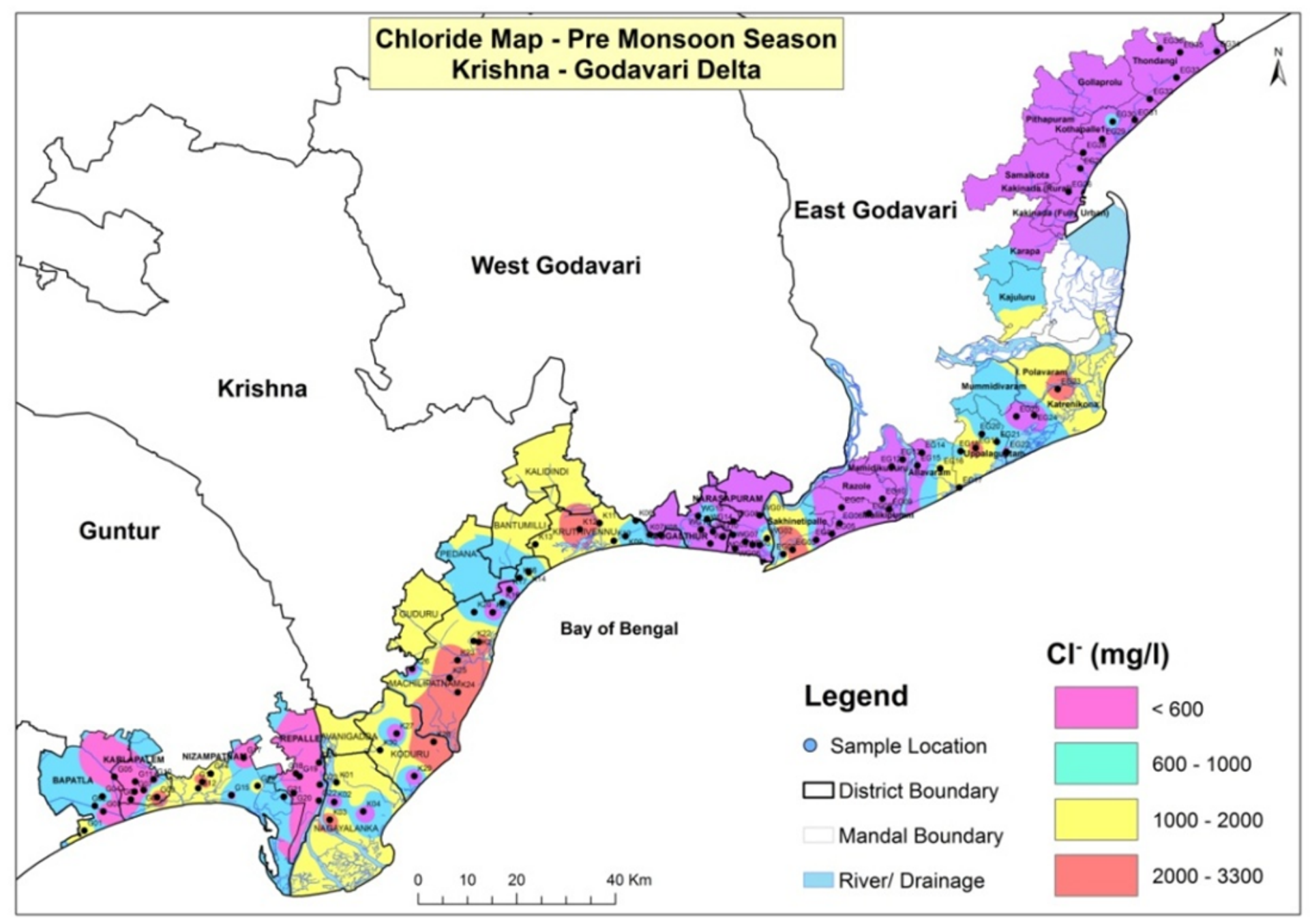

Figure 10

Chloride map for pre-monsoon season Note: The designations employed and the presentation of the material on this map do not imply the expression of any opinion whatsoever on the part of Research Square concerning the legal status of any country, territory, city or area or of its authorities, or concerning the delimitation of its frontiers or boundaries. This map has been provided by the authors. 


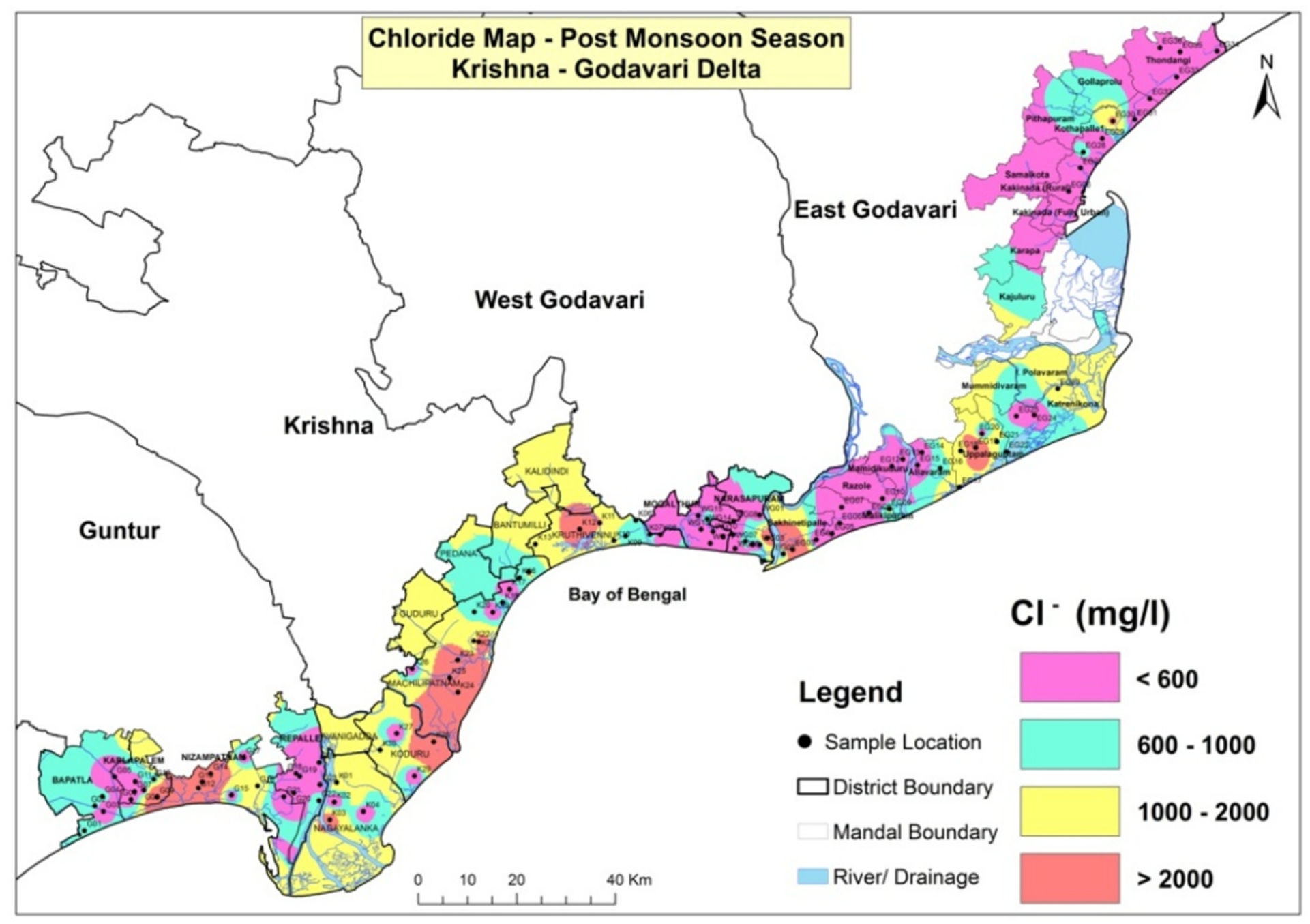

Figure 11

Chloride map for post-monsoon season Note: The designations employed and the presentation of the material on this map do not imply the expression of any opinion whatsoever on the part of Research Square concerning the legal status of any country, territory, city or area or of its authorities, or concerning the delimitation of its frontiers or boundaries. This map has been provided by the authors. 


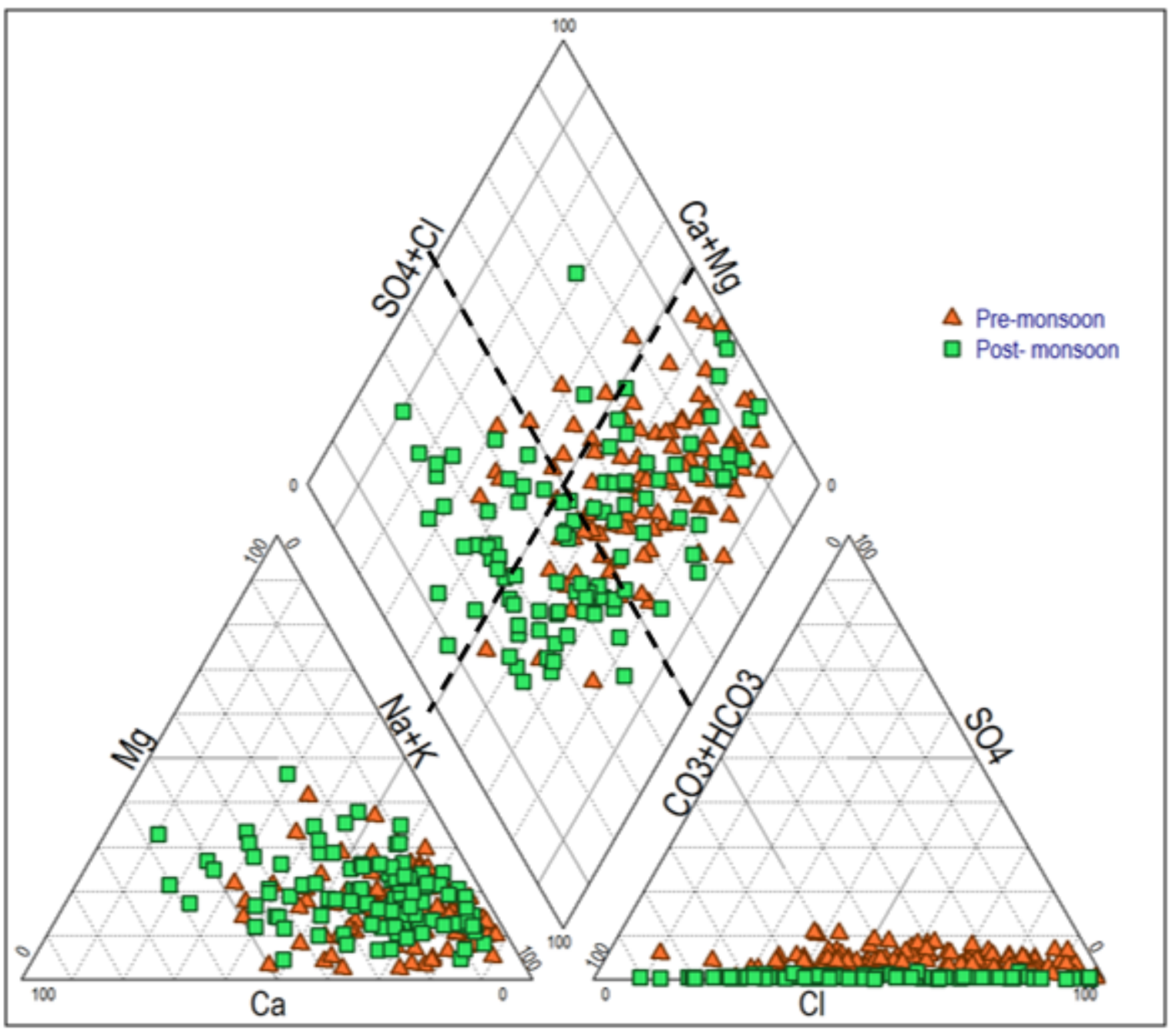

Figure 12

Water-types according to Piper diagram 


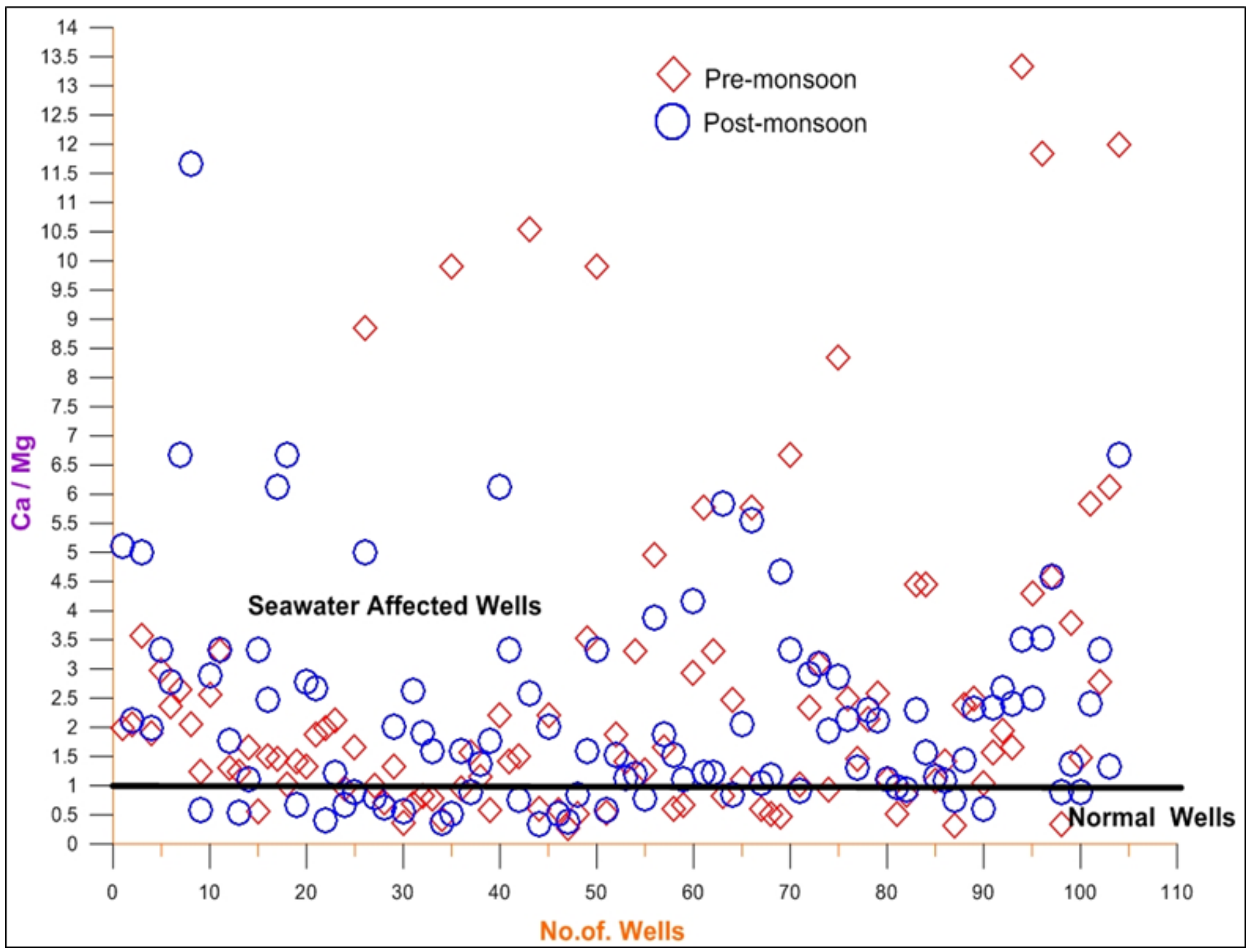

Figure 13

$\mathrm{Ca} / \mathrm{Mg}$ ratio values in the study area

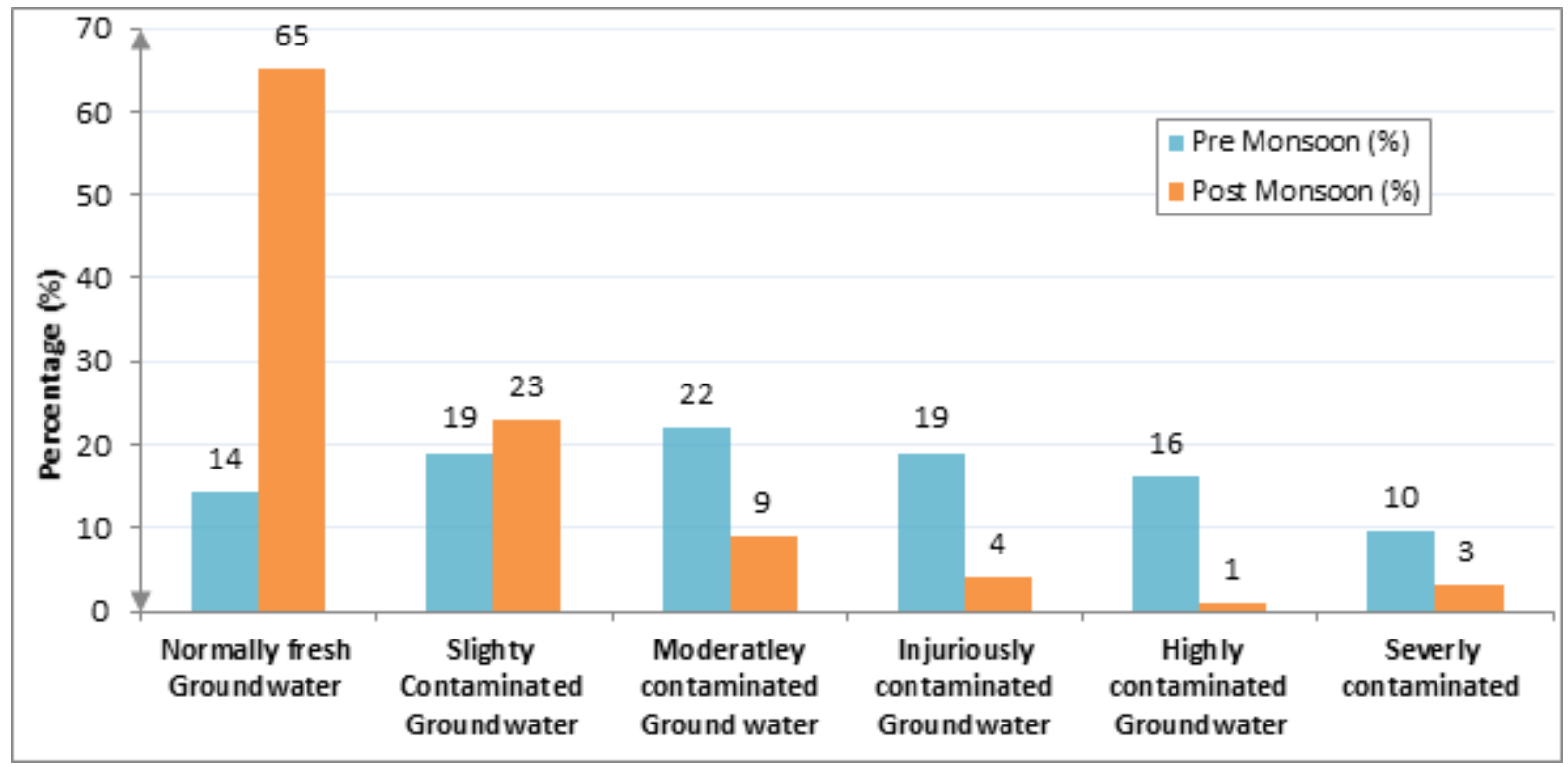


Figure 14

Contamination in the study area based on $\mathrm{Cl} /(\mathrm{CO} 3+\mathrm{HCO})$ in Pre-monsoon Season (2016) and Postmonsoon Season (2017)

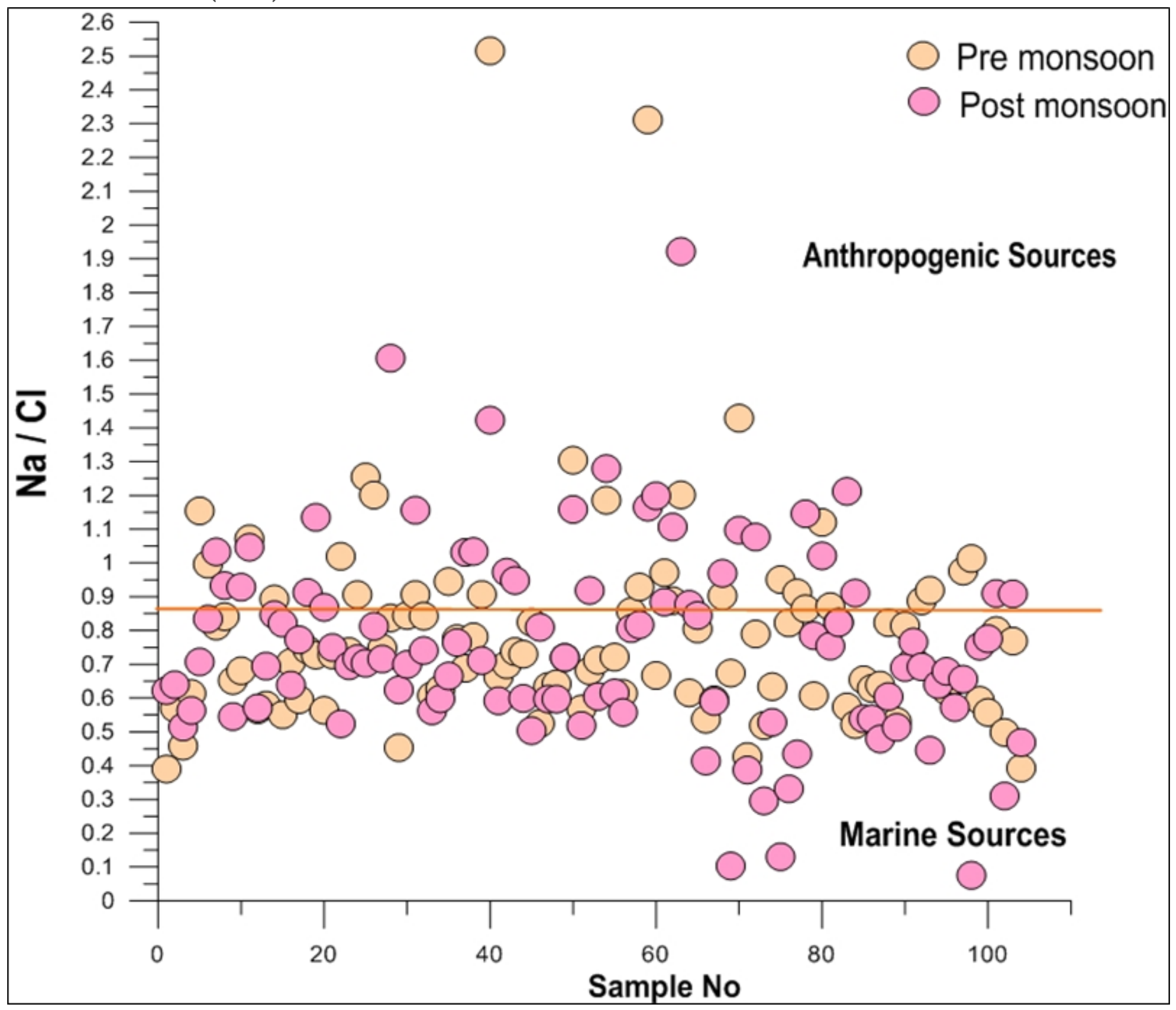

Figure 15

Source of contamination based on the $\mathrm{Na} / \mathrm{Cl}$ Ratio 


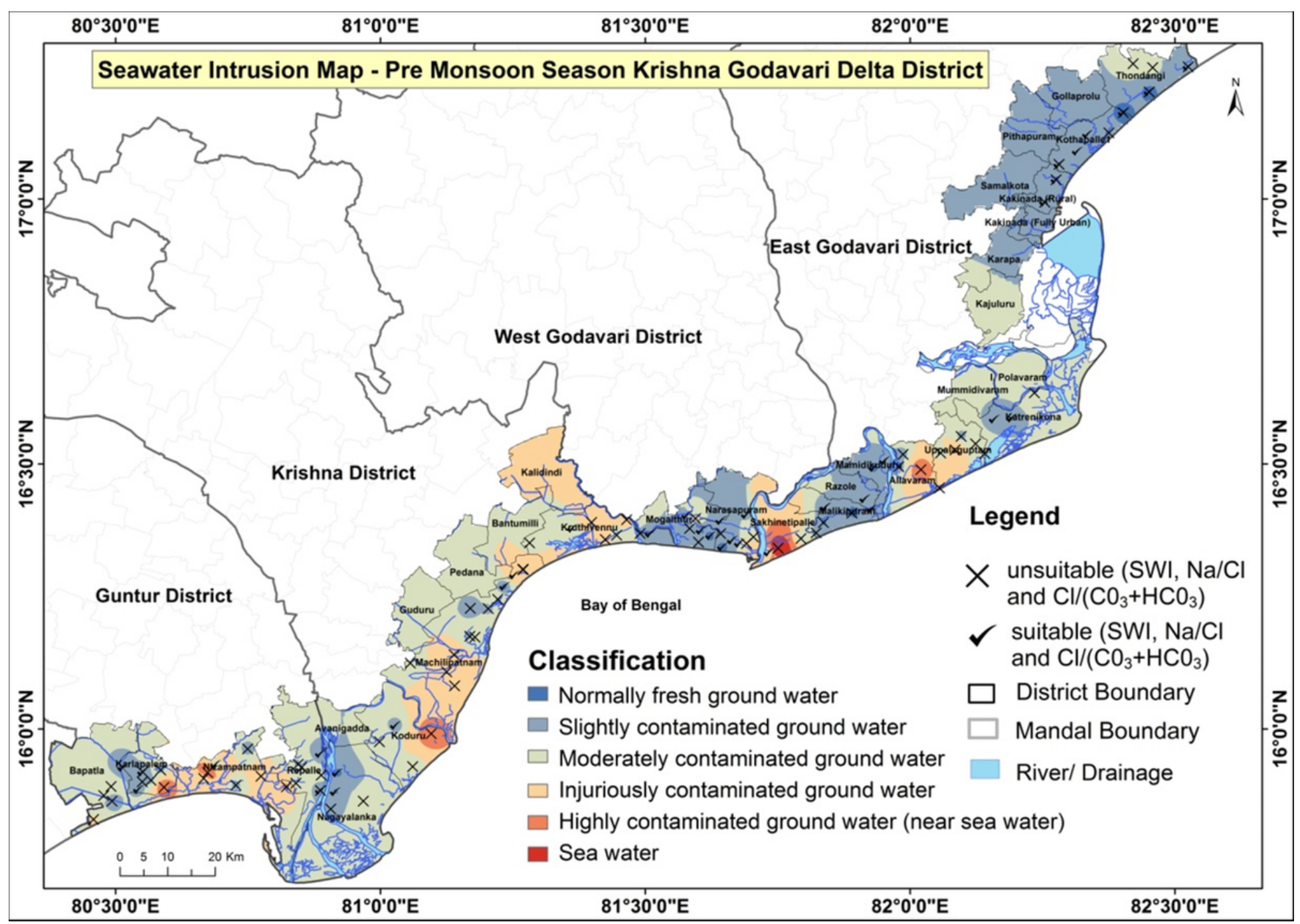

Figure 16

Classification based on suitability of groundwater for drinking purposes Pre-monsoon (2016) Note: The designations employed and the presentation of the material on this map do not imply the expression of any opinion whatsoever on the part of Research Square concerning the legal status of any country, territory, city or area or of its authorities, or concerning the delimitation of its frontiers or boundaries. This map has been provided by the authors. 


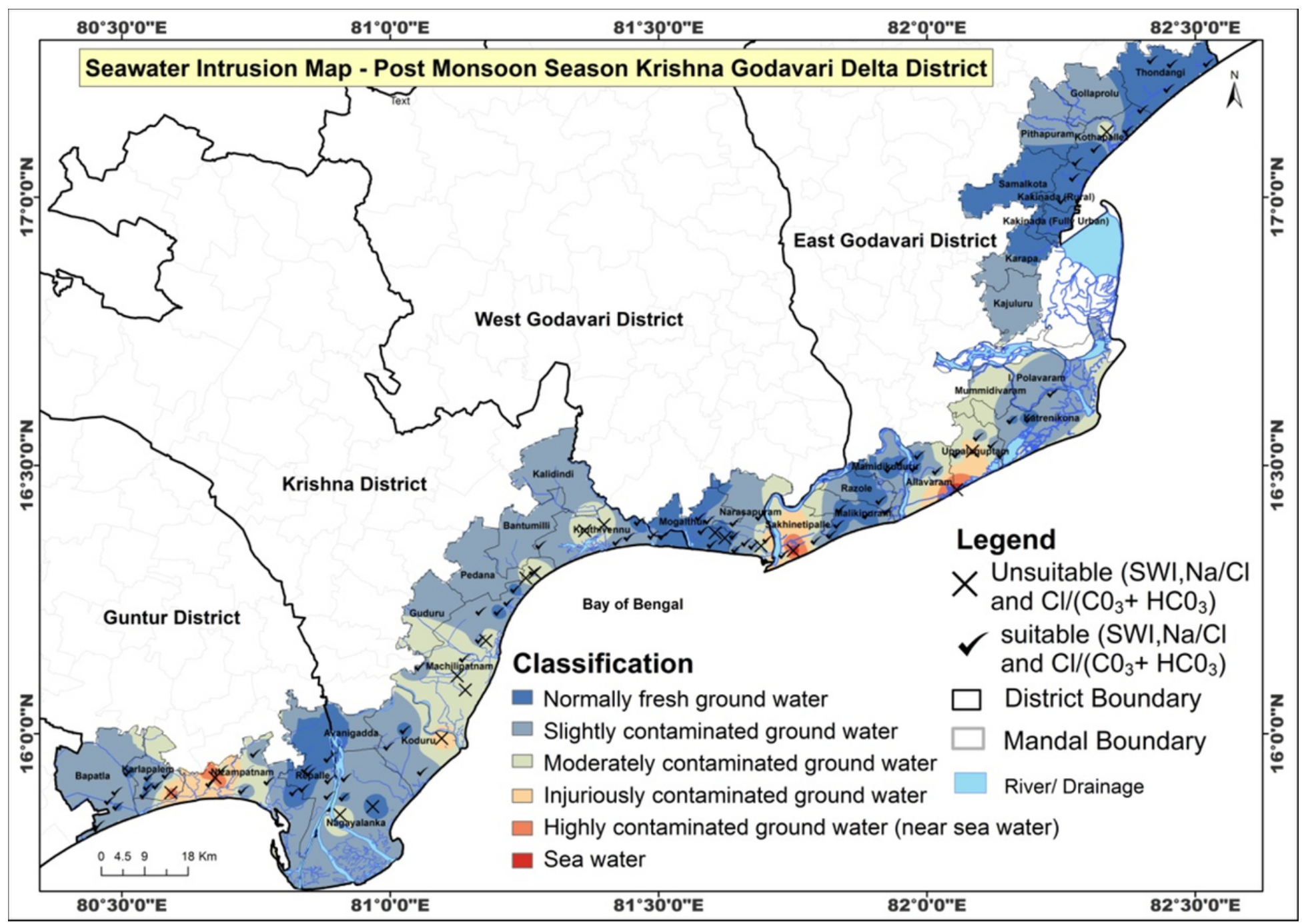

Figure 17

Classification based on suitability of groundwater for drinking purposes Post-monsoon (2017) Note: The designations employed and the presentation of the material on this map do not imply the expression of any opinion whatsoever on the part of Research Square concerning the legal status of any country, territory, city or area or of its authorities, or concerning the delimitation of its frontiers or boundaries. This map has been provided by the authors. 